\title{
Geology and Assessment of Undiscovered Oil and Gas Resources of the Amerasia Basin Province, 2008
}

Chapter BB of

The 2008 Circum-Arctic Resource Appraisal

Professional Paper 1824

Supersedes USGS Scientific Investigations Report 2012-5146

U.S. Department of the Interior

U.S. Geological Survey 
COVER. Eocene strata along the north side of Van Keulenfjorden, Svalbard, include basin-floor fan, marine slope, and deltaic to fluvial depositional facies. The age and facies of these strata are similar to Tertiary strata beneath the continental shelves of the Amerasia Basin, thus providing an analog for evaluating elements of the petroleum system. Relief from sea level to top of upper bluff is approximately 1,500 feet. 


\section{Geology and Assessment of Undiscovered Oil and Gas Resources of the Amerasia Basin Province, 2008}

By David W. Houseknecht, Kenneth J. Bird, and Christopher P. Garrity

Chapter BB of

The 2008 Circum-Arctic Resource Appraisal

Edited by T.E. Moore and D.L. Gautier

Professional Paper 1824

Supersedes USGS Scientific Investigations Report 2012-5146 


\title{
U.S. Department of the Interior \\ DAVID BERNHARDT, Secretary
}

\section{U.S. Geological Survey James F. Reilly II, Director}

\author{
U.S. Geological Survey, Reston, Virginia: 2020 \\ Supersedes USGS Scientific Investigations Report 2012-5146
}

For more information on the USGS - the Federal source for science about the Earth, its natural and living resources, natural hazards, and the environment-visit https://www.usgs.gov or call 1-888-ASK-USGS.

For an overview of USGS information products, including maps, imagery, and publications,

visit https://store.usgs.gov.

Any use of trade, firm, or product names is for descriptive purposes only and does not imply endorsement by the U.S. Government.

Although this information product, for the most part, is in the public domain, it also may contain copyrighted materials as noted in the text. Permission to reproduce copyrighted items must be secured from the copyright owner.

Suggested citation:

Houseknecht, D.W., Bird, K.J., and Garrity, C.P., 2020, Geology and assessment of undiscovered oil and gas resources of the Amerasia Basin Province, 2008, chap. BB of Moore, T.E., and Gautier, D.L., eds., The 2008 Circum-Arctic Resource Appraisal: U.S. Geological Survey Professional Paper 1824, 33 p., https://doi.org/10.3133/pp1824BB. [Supersedes USGS Scientific Investigations Report 2012-5146.]

ISSN 2330-7102 (online) 


\section{The 2008 Circum-Arctic Resource Appraisal}

Chapter A. Introduction to the 2008 Circum-Arctic Resource Appraisal (CARA) Professional Paper By Donald L. Gautier and Thomas E. Moore

Chapter B. Methodology for Assessment of Undiscovered Oil and Gas Resources for the 2008 Circum-Arctic Resource Appraisal

By Ronald R. Charpentier

\section{North America}

Chapter C. Geology and Assessment of Undiscovered Oil and Gas Resources of the Chukchi Borderland Province, 2008

By Kenneth J. Bird and David W. Houseknecht

Chapter D. Geology and Undiscovered Oil and Gas Resources of the Hope Basin Province, 2008

By Kenneth J. Bird, David W. Houseknecht, and Janet K. Pitman

Chapter E. Geology and Assessment of Undiscovered Oil and Gas Resources of the Arctic Alaska Petroleum Province, 2008

By David W. Houseknecht, Kenneth J. Bird, and Christopher P. Garrity

Chapter F. Geology and Assessment of Undiscovered Oil and Gas Resources of the Central Alaska Province, 2008

By Kenneth J. Bird and Richard G. Stanley

Chapter G. Geology and Assessment of Undiscovered Oil and Gas Resources of the Northwest Canada Interior Basins Province, Arctic Canada, 2008

By Marilyn E. Tennyson and Janet K. Pitman

Chapter H. Geology and Assessment of Undiscovered Oil and Gas Resources of the Franklinian Shelf Province, Arctic Canada and North Greenland, 2008

By Marilyn E. Tennyson and Janet K. Pitman

Chapter I. Geology and Assessment of Undiscovered Oil and Gas Resources of the Sverdrup Basin

Province, Arctic Canada, 2008

By Marilyn E. Tennyson and Janet K. Pitman

\section{Greenland}

Chapter J. Geology and Assessment of Undiscovered Oil and Gas Resources of the West GreenlandEast Canada Province, 2008

By Christopher J. Schenk

Chapter K. Geology and Assessment of Undiscovered Oil and Gas Resources of the East Greenland Rift Basins Province, 2008

By Donald L. Gautier 


\section{North Atlantic Ocean}

Chapter L. Geology and Assessment of Undiscovered Oil and Gas Resources of the Jan Mayen Microcontinent Province, 2008

By Thomas E. Moore and Janet K. Pitman

\section{Eurasia}

Chapter M. Geology and Assessment of Undiscovered Oil and Gas Resources of the Mezen' Basin Province, 2008

By Timothy R. Klett and Janet K. Pitman

Chapter N. Geology and Assessment of Undiscovered Oil and Gas Resources of the Timan-Pechora Basin Province, Russia, 2008

By Christopher J. Schenk

Chapter 0. Geology and Assessment of Undiscovered Oil and Gas Resources of the East Barents Basins Province and the Novaya Zemlya Basins and Admiralty Arch Province, 2008

By Timothy R. Klett

Chapter P. Geology and Assessment of Undiscovered Oil and Gas Resources of the North Kara Basins and Platforms Province, 2008

By Timothy R. Klett and Janet K. Pitman

Chapter 0. Geology and Assessment of Undiscovered Oil and Gas Resources of the Northern West Siberian Mesozoic Composite Total Petroleum System of the West Siberian Basin Province, Russia, 2008

By Christopher J. Schenk

Chapter R. Geology and Assessment of Undiscovered Oil and Gas Resources of the Yenisey-Khatanga Basin Province, 2008

By Timothy R. Klett and Janet K. Pitman

Chapter S. Geology and Assessment of Undiscovered Oil and Gas Resources of the Northwest Laptev Sea Shelf Province, 2008

By Timothy R. Klett and Janet K. Pitman

Chapter T. Geology and Assessment of Undiscovered Oil and Gas Resources of the Lena-Anabar Basin Province, 2008

By Timothy R. Klett and Janet K. Pitman

Chapter U. Geology and Assessment of Undiscovered Oil and Gas Resources of the Tunguska Basin Province, 2008

By Craig J. Wandrey and Timothy R. Klett

Chapter V. Geology and Assessment of Undiscovered Oil and Gas Resources of the Lena-Vilyui Basin Province, 2008

By Timothy R. Klett and Janet K. Pitman 
Chapter W. Geology and Assessment of Undiscovered Oil and Gas Resources of the Laptev Sea Shelf Province, 2008

By Timothy R. Klett and Janet K. Pitman

Chapter X. Geology and Assessment of Undiscovered Oil and Gas Resources of the Zyryanka Basin Province, 2008

By Timothy R. Klett and Janet K. Pitman

Chapter Y. Geology and Assessment of Undiscovered Oil and Gas Resources of the East Siberian Sea Basin Province, 2008

By Kenneth J. Bird, David W. Houseknecht, and Janet K. Pitman

Chapter Z. Geology and Assessment of Undiscovered Oil and Gas Resources of the Vilkitskii Basin Province, 2008

By Kenneth J. Bird, David W. Houseknecht, and Janet K. Pitman

Chapter AA. Geology and Assessment of Undiscovered Oil and Gas Resources of the Long Strait Basin Province, 2008

By Kenneth J. Bird, David W. Houseknecht, and Janet K. Pitman

Chapter BB. Geology and Assessment of Undiscovered Oil and Gas Resources of the Amerasia Basin Petroleum Province, 2008

By David W. Houseknecht, Kenneth J. Bird, and Christopher P. Garrity

\section{Arctic Ocean}

Chapter CC. Geology and Assessment of Undiscovered Oil and Gas Resources of the LomonosovMakarov Province, 2008

By Thomas E. Moore, Kenneth J. Bird, and Janet K. Pitman

Chapter DD. Geology and Assessment of Undiscovered Oil and Gas Resources of the Eurasia Basin Province, 2008

By Thomas E. Moore and Janet K. Pitman 


\section{Contents}

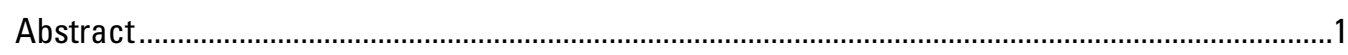

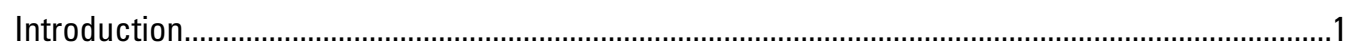

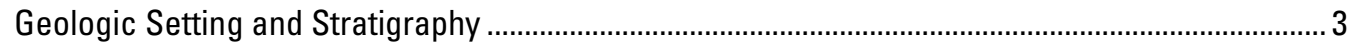

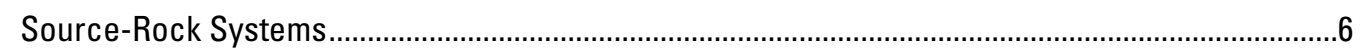

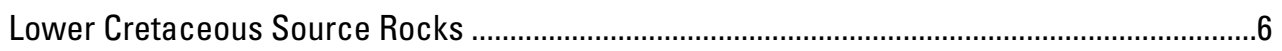

Upper Cretaceous Source Rocks.....................................................................................

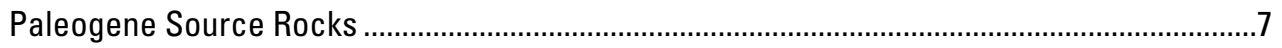

Canning-Mackenzie Deformed Margin Assessment Unit ...........................................................12

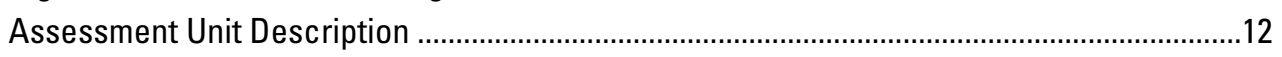

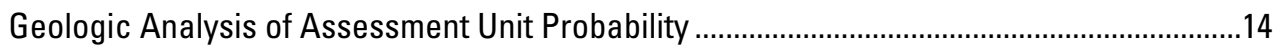

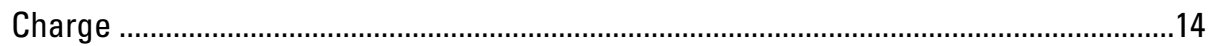

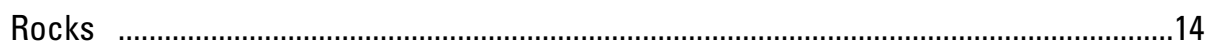

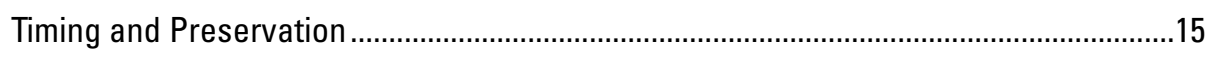

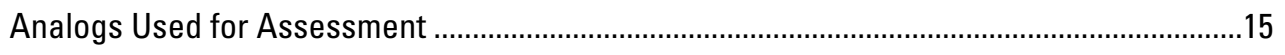

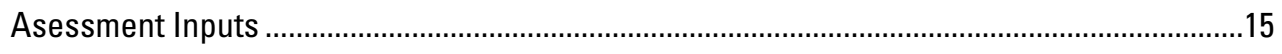

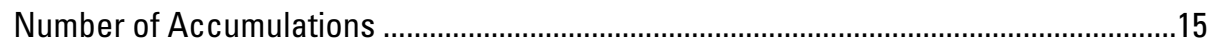

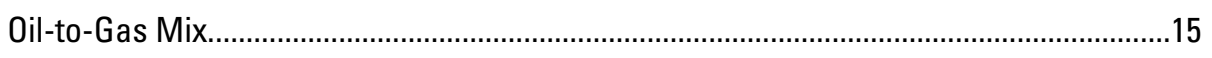

Accumulation Size Distribution ...............................................................................15

Estimated Maximum Accumulation Size .....................................................15

Ancillary Properties and Co-Product Ratios ..................................................15

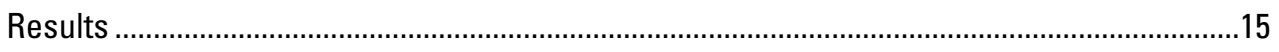

Alaska Passive Margin Assessment Unit ..............................................................................18

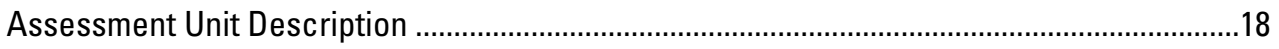

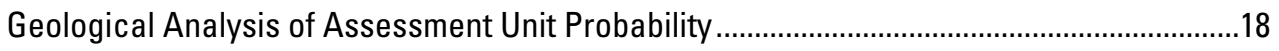

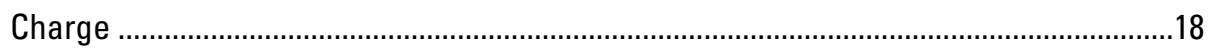

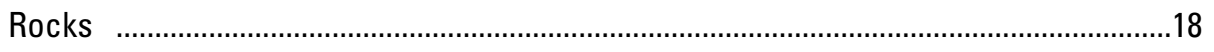

Timing and Preservation ...................................................................................2

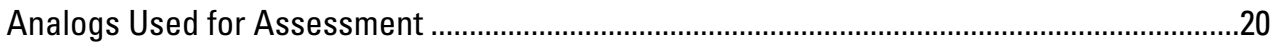

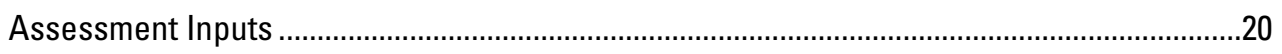

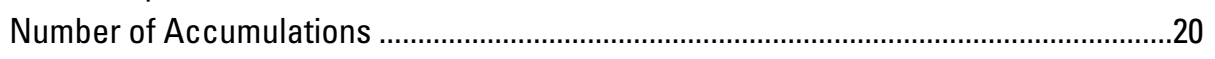

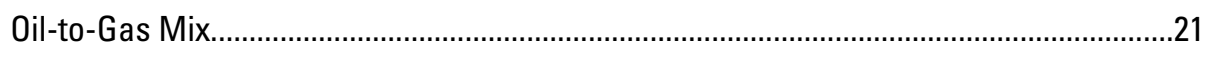

Accumulation Size Distribution ..........................................................................21

Province Geologist's Estimated Maximum Accumulation Size .......................................21

Ancillary Properties and Co-Product Ratios ................................................................21

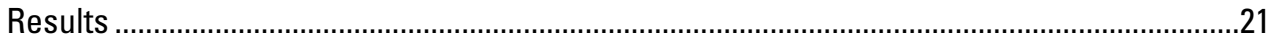

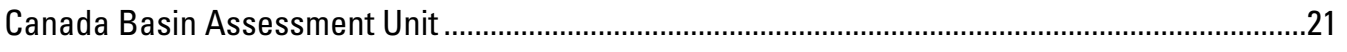

Assessment Unit Description ........................................................................................2

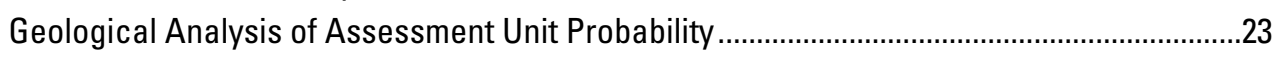

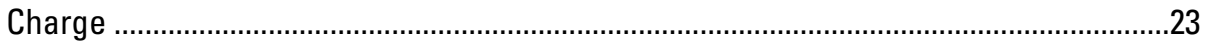

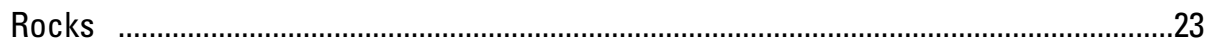

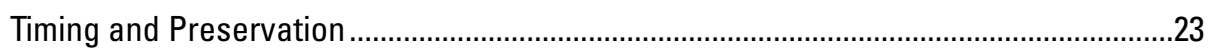

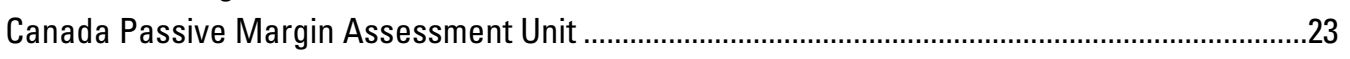

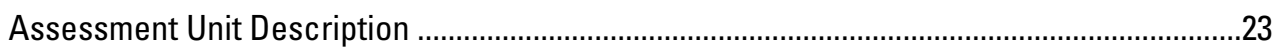


Geologic Analysis of Assessment Unit Probability ...............................................................2

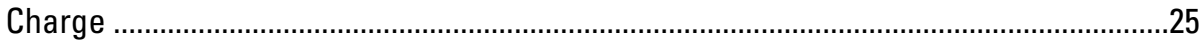

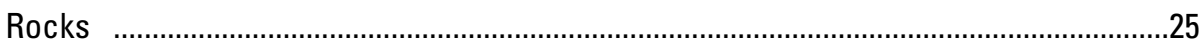

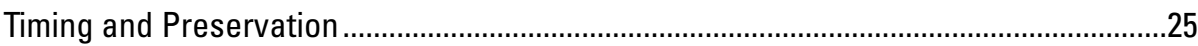

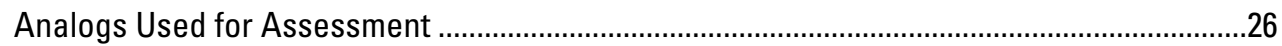

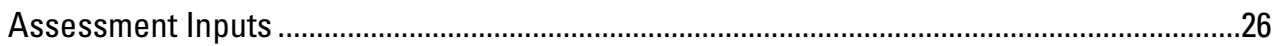

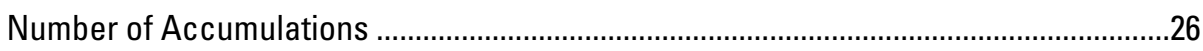

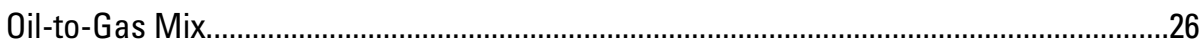

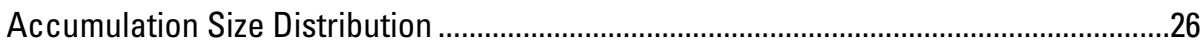

Province Geologist's Estimated Maximum Accumulation Size .........................................26

Ancillary Properties and Co-Product Ratios ...............................................................26

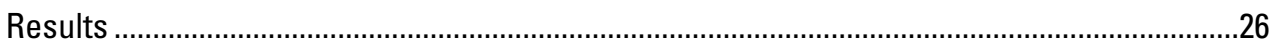

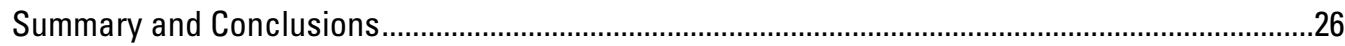

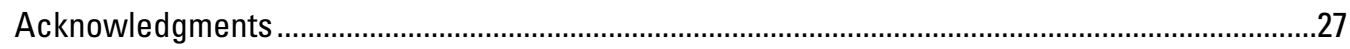

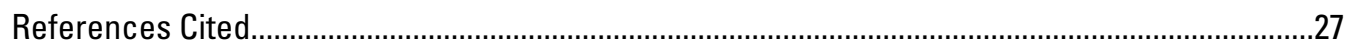

\section{Figures}

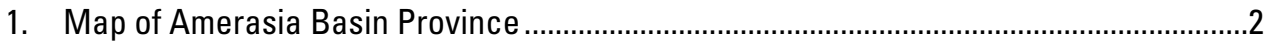

2. Generalized representative cross sections across the Alaska rift shoulder and southern Canada Basin .................................................................................................

3. Generalized cross section across the Canada rifted passive margin and extending into the Canada Basin .....................................................................................................

4. Cross-bedded pebbly sandstone in Paleogene strata exposed along the Sagavanirktok River, Alaska North Slope .........................................................................

5. Plots of depth versus vitrinite reflectance for representative wells from the Canning-Mackenzie Deformed Margin Assessment Unit ..................................................8

6. Petroleum systems plots for five pseudowells and one well in the Amerasia Basin

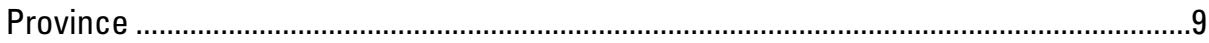

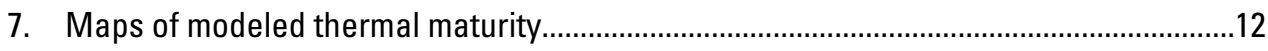

8. Map of the Canning-Mackenzie Deformed Margin Assessment Unit..............................13

9. Map of the Alaska Passive Margin Assessment Unit ....................................................19

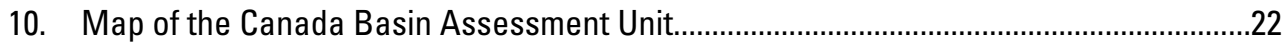

11. Map of the Canada Passive Margin Assessment Unit.....................................................24 


\section{Tables}

1. Analog assessment units used to constrain input parameters for the Canning-Mackenzie Deformed Margin Assessment Unit. Analog data from Charpentier and others (2008)

2. Summary of results for risked, undiscovered, technically recoverable petroleum resources for the Amerasia Basin Province, including results for the Canning-Mackenzie Deformed Margin, Alaska Passive Margin, Canada Basin, and Canada Passive Margin Assessment Units

3. Assessment units used to constrain input parameters for the Alaska Passive Margin and Canada Passive Margin Assessment Units. Analog data from Charpentier and others (2008)

\section{Appendixes}

[Available for download at https://doi.org/10.3133/pp1824BB]

1. Input data for the Canning-Mackenzie Deformed Margin Assessment Unit

2. Input data for the Alaska Passive Margin Assessment Unit

3. Input data for Canada Passive Margin Assessment Unit.

\section{Conversion Factors}

\begin{tabular}{|c|c|c|}
\hline Multiply & By & To obtain \\
\hline \multicolumn{3}{|c|}{ Length } \\
\hline meter $(\mathrm{m})$ & 3.281 & foot $(\mathrm{ft})$ \\
\hline meter $(\mathrm{m})$ & 1.094 & yard (yd) \\
\hline kilometer $(\mathrm{km})$ & 0.6214 & mile (mi) \\
\hline kilometer $(\mathrm{km})$ & 0.5400 & mile, nautical (nmi) \\
\hline \multicolumn{3}{|c|}{ Area } \\
\hline square kilometer $\left(\mathrm{km}^{2}\right)$ & 247.1 & acre \\
\hline square kilometer $\left(\mathrm{km}^{2}\right)$ & 0.3861 & square mile $\left(\mathrm{mi}^{2}\right)$ \\
\hline \multicolumn{3}{|c|}{ Volume } \\
\hline $\begin{array}{l}\text { barrel (bbl), (petroleum, } \\
1 \text { barrel=42 gal) }\end{array}$ & 0.1590 & cubic meter $\left(\mathrm{m}^{3}\right)$ \\
\hline cubic foot $\left(\mathrm{ft}^{3}\right)$ & 28.32 & cubic decimeter $\left(\mathrm{dm}^{3}\right)$ \\
\hline cubic foot $\left(\mathrm{ft}^{3}\right)$ & 0.02832 & cubic meter $\left(\mathrm{m}^{3}\right)$ \\
\hline
\end{tabular}




\title{
Geology and Assessment of Undiscovered Oil and Gas Resources of the Amerasia Basin Province, 2008
}

\author{
By David W. Houseknecht, Kenneth J. Bird, and Christopher P. Garrity
}

\section{Abstract}

The Amerasia Basin Province encompasses the Canada Basin and the sediment prisms along the Alaska and Canada margins, outboard from basinward margins (hingelines) of the rift shoulders that formed during extensional opening of the Canada Basin. The province includes the Mackenzie River delta and slope, the outer shelves and marine slopes along the Arctic margins of Alaska and Canada, and the deep Canada Basin.

The province is divided into four assessment units (AUs): (1) The Canning-Mackenzie Deformed Margin AU is that part of the rifted margin where the Brooks Range orogenic belt has overridden the rift shoulder and is deforming the rifted-margin prism of sediment outboard of the hingeline. This is the only part of the Amerasia Basin Province that has been explored and - even though more than 3 billion barrels of oil equivalent (BBOE) of oil, gas, and condensate have been discoverednone has been commercially produced. (2) The Alaska Passive Margin AU is the rifted-margin prism of sediment lying beneath the Beaufort Sea outer shelf and slope that has not been deformed by tectonism. (3) The Canada Passive Margin AU is the rifted-margin prism of sediment lying beneath the Arctic outer shelf and slope (also known as the polar margin) of Canada that has not been deformed by tectonism. (4) The Canada Basin AU includes the sedimentary wedge that lies beneath the deep Canada Basin, north of the marine slope developed along the Alaska and Canada margins. Mean estimates of risked, undiscovered, technically recoverable resources include more than 6 billion barrels of oil (BBO), more than 19 trillion cubic feet (TCF) of associated gas, and more than 16 TCF of nonassociated gas in the CanningMackenzie Deformed Margin AU; about 1 BBO, about 3 TCF of associated gas, and about 3 TCF of associated gas in the Alaska Passive Margin AU; and more than 2 BBO, about 7 TCF of associated gas, and about 8 TCF of nonassociated gas in the Canada Passive Margin AU. Quantities of natural gas liquids also are assessed in each AU. The Canada Basin AU was not quantitatively assessed because it is judged to hold

\footnotetext{
${ }^{1}$ The term "Canada Basin" is used in this report as the deepwater (generally more than 3,000 $\mathrm{m}$ water depth) part of the Amerasia Basin that includes a sedimentary succession inferred to be thicker than about $2,000 \mathrm{~m}$.
}

less than 10 percent probability of containing at least one accumulation of 50 million barrels of oil equivalent.

\section{Introduction}

The U.S. Geological Survey (USGS) in 2008 completed an appraisal of undiscovered, technically recoverable, conventional oil and gas resources north of the Arctic Circle. Results of that Circum-Arctic Resource Appraisal include aggregate resource estimates for the entire Arctic region (Bird and others, 2008; Gautier and others, 2009, 2011a) and documentation of the geological framework and resource estimates for specific Arctic provinces (Bird and Houseknecht, 2011; Gautier and others, 2011b; Houseknecht and Bird, 2011; Klett and Pitman, 2011; Klett and others, 2011; Moore and Pitman, 2011; Moore and others, 2011; Schenk, 2011a, b; Sørensen and others, 2011). In addition, the procedures and methods used in conducting the Circum-Arctic Resource Appraisal have been documented by Charpentier and Gautier (2011) and Charpentier (2017 [this volume]). The purpose of this report is to provide a synthesis of the geology of the Amerasia Basin Province and to present input parameters and results of the resource assessment.

The Amerasia Basin includes that part of the Arctic Ocean that lies between the Lomonosov Ridge, the Arctic continental shelves of Canada and Alaska, the Chukchi shelf of Alaska and Russia, and the East Siberian shelf of Russia (Grantz and others, 2009, 2011b). For assessment purposes, we define the Amerasia Basin Province to include the deep Canada Basin ${ }^{1}$ and the depocenters along the continental margins of Alaska and Canada (fig. 1). Elements of the Amerasia Basin that are excluded from consideration in this report include the "Alpha-Mendeleev large igneous province," which was deemed nonprospective for oil and gas by Grantz and others (2009, 2011b), and the Chukchi Borderland and Makarov basins, which are considered in other chapters of the 2008 Circum-Artic Resource Appraisal.

As defined, the Amerasia Basin Province extends about $1,200 \mathrm{~km}$ west-east along the $73^{\circ} \mathrm{N}$. parallel and ranges from about 1,100 km north-south in the west (adjacent to the Chukchi Borderland) to about 2,250 km northeast-southwest 
in the east (along the Canada continental margin) (fig. 1). The western, southern, and eastern boundaries of the province are defined by the outboard (basinward) margins of rift shoulders that formed during the opening of the Amerasia Basin during Jurassic-Early Cretaceous time (Embry, 1990; Grantz and others, 1990b, 1998, 2011a; Lane, 1997; Lawver and Scotese, 1990). The north-central boundary is defined by abrupt thinning of Canada Basin strata onto extrusive rocks of the
Alpha-Mendeleev igneous province. The northeastern boundary is defined by abrupt thinning of strata from the Canada continental margin onto extrusive rocks of the Alpha ridge. Additional details regarding these boundaries are included in the assessment unit descriptions that follow. The province is divided into four units for assessment purposes: the CanningMackenzie Deformed Margin, the Alaska Passive Margin, the Canada Basin, and the Canada Passive Margin (fig.1).

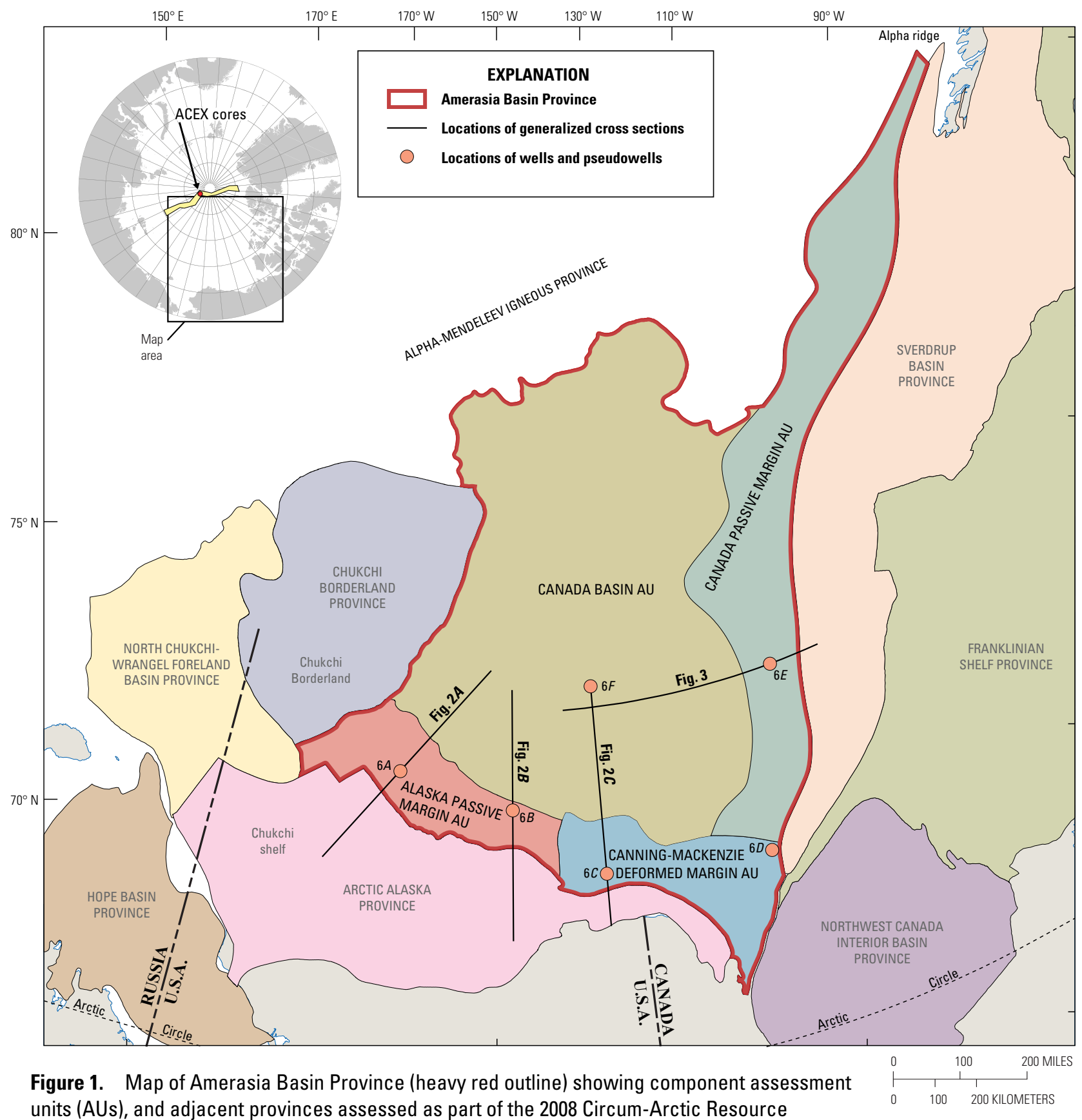
units (AUs), and adjacent provinces assessed as part of the 2008 Circum-Arctic Resource Appraisal. Black lines labeled figures $2 A, 2 B, 2 C$ and 3 are locations of generalized cross sections shown in figures 2 and 3 . Salmon-colored circles (labeled $6 A-6 F$ ) are locations of wells and pseudowells for which petroleum-system plots are shown in figure 6. Inset map shows location of study area, Lomonosov Ridge (yellow polygon), and location of ACEX cores. 


\section{Geologic Setting and Stratigraphy}

The Canada Basin formed by Jurassic-Early Cretaceous rifting between Alaska and Arctic Canada. The Arctic Alaska microplate (including Arctic Alaska, the Chukchi shelf, and the Chukchi Borderland; fig. 1) rifted from Arctic Canada, perhaps by counterclockwise rotational opening of the Canada Basin or alternative motions (Grantz and May, 1982; Lawver and Scotese, 1990; Grantz and others, 1990b, 2011a; Embry, 1990, 2000; Lane, 1997; Lawver and others, 2002, 2011). The Chukchi Borderland, composed of attenuated continental crust, is inferred to have rotated clockwise away from Arctic Alaska (Grantz and others, 2009b, 2011a), either during or after opening of the Canada Basin.

The Arctic margins of Alaska and Canada, as well as the eastern margin of the Chukchi Borderland (Northwind Ridge; Grantz and others, 1998), are defined by high-standing acoustic basement that represents the rift shoulders formed during extensional opening of the Canada Basin (Houseknecht and Bird, 2011). The outboard margins of those rift shoulders are defined by large-magnitude, down-to-the-basin normal faults in acoustic basement (figs. 2, 3); these abrupt margins commonly are called hinges or hingelines (fig. 2). These hinges separate thick continental crust beneath the Chukchi Borderland, Arctic Alaska, and Arctic Canada from highly attenuated continental to transitional crust beneath the Canada Basin. The hinges are used herein to define the western, southern, and eastern limits of the Amerasia Basin Province because of the inferred contrasts in petroleum systems across those abrupt boundaries, as explained below (Houseknecht and others, 2012b).

Acoustic basement inboard from the hinges (west of the hinge in the Chukchi Borderland, south of the hinge in Arctic Alaska, and southeast of the hinge in Arctic Canada) mostly consists of pre-Mississippian, low-rank metamorphic rocks known as the Franklinian sequence (figs. 2, 3), which was broadly deformed during the Ellesmerian orogeny (Late Devonian-Early Mississippian; Balkwill and others, 1983; Moore and others, 1994; Dumoulin, 2001). Immediately outboard (basinward) of the hinges, acoustic basement presumably consists of similar rocks that are highly attenuated. Farther basinward, basement may grade into transitional crust by attenuation and intrusion by oceanic igneous rocks, but this inference is poorly constrained. Basement in the center of the Canada Basin may be fully oceanic crust, as suggested by the presence of magnetic stripes (Grantz and others, 2011a).

Pre-Cenozoic stratigraphy of the Amerasia Basin is poorly known because the southern and eastern margins of the province are mantled by such a thick succession of Cenozoic sediment that neither exploration wells nor seismic data provide much information regarding older strata. Therefore, the presence and nature of sub-Cenozoic strata must be inferred from the geology of adjacent regions and other indirect evidence. Jurassic-Lower Cretaceous synrift deposits are evident in seismic data and have been penetrated by drilling along parts of the rift shoulder (Grantz and May, 1982; Hubbard and others, 1987; Masterson and Paris, 1987; Masterson and Eggert, 1992). However, any synrift deposits outboard of the hinge are deeply buried beneath an expanding wedge of postrift strata, which thicken dramatically by growth-faulting north of the rift shoulder (figs. 2, 3).

The postrift succession in the Amerasia Basin probably includes Lower Cretaceous through Cenozoic strata. These strata include (1) the Brookian sequence in Arctic Alaska and the Canadian Beaufort-Mackenzie region (Lerand, 1973; Hubbard and others, 1987), whose sediment was derived mostly from the Chukotka magmatic belt and Brooks Range orogenic belt (fig. 4), and (2) coeval strata of the Canadian Arctic islands and adjacent shelf, whose sediment probably was derived from a mixed provenance that included the Canadian shield, Franklinian shelf, Sverdrup basin, Sverdrup rim (rift shoulder), and Eurekan tectonic uplifts (Miall, 1984, 1986, 1991; McWhae, 1986; Haimila and others, 1990; Embry, 1991, 1993; Harrison and others, 1999; Houseknecht and Bird, 2011). Coeval strata in the deep Canada Basin may represent a distal mixture of sediment derived from all these provenance areas, plus contributions from the Chukchi Borderland and perhaps the Alpha-Mendeleev igneous province (fig. 1).

Data from exploration wells and seismic surveys indicate that significant volumes of sediment initially overstepped the rift shoulder during the Albian along the northeast Chukchi and western Alaska North Slope margin and during the Paleogene along the central and eastern Alaska North Slope margin (Houseknecht and others, 2009, 2012b; Houseknecht andBird, 2011). Inferences from the Mackenzie delta and Arctic Islands of Canada suggest that modest volumes of sediment may have overstepped the rift shoulder (Sverdrup rim) during the Cretaceous and that the most voluminous influx occurred during the Tertiary, largely a consequence of uplift associated with the Brooks Range orogeny (sediment fed through the Mackenzie delta) and the Eurekan orogeny (Miall, 1984, 1986; Hubbard and others, 1987; Dixon and Dietrich, 1990; Dixon and others, 1992; Dixon, 1996; Forsyth and others, 1990, 1998; Harrison and others, 1999; Houseknecht and Bird, 2011). Considering that the Amerasia Basin likely was fully open by the Barremian (Grantz and others, 2011a), the succession deposited after the Barremian and before the flood of Brookian Alaska-Mackenzie margin) and Eurekan (Canadian Arctic islands margin) sediment holds the potential to include condensed facies (see below). 
The 2008 Circum-Arctic Resource Appraisal

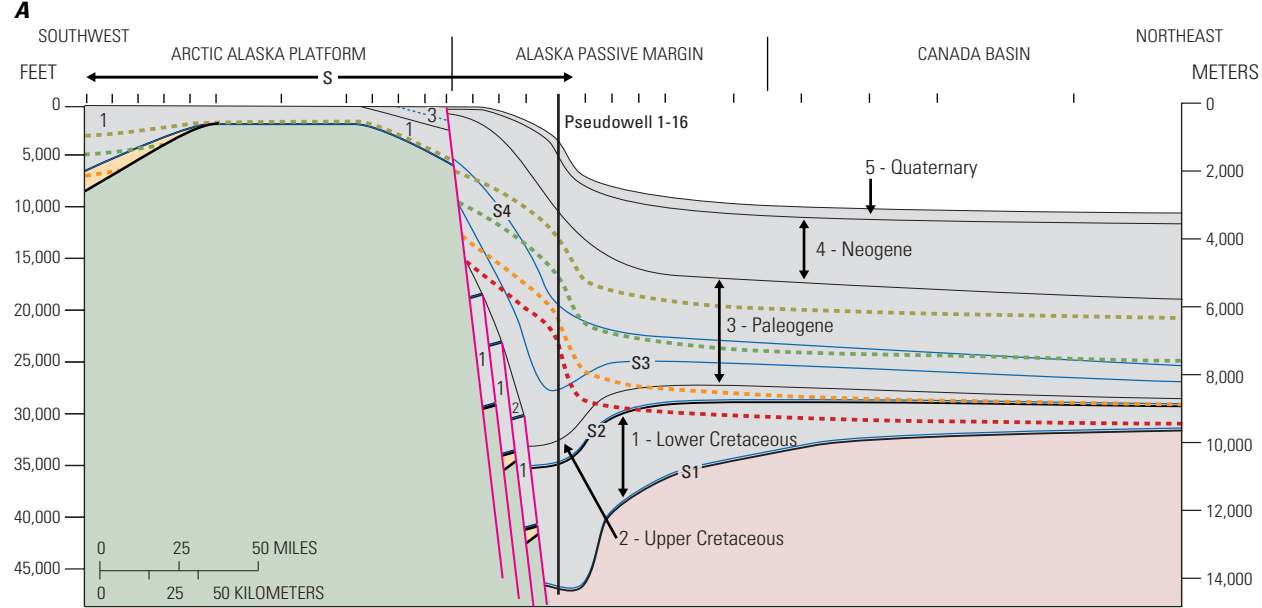

B
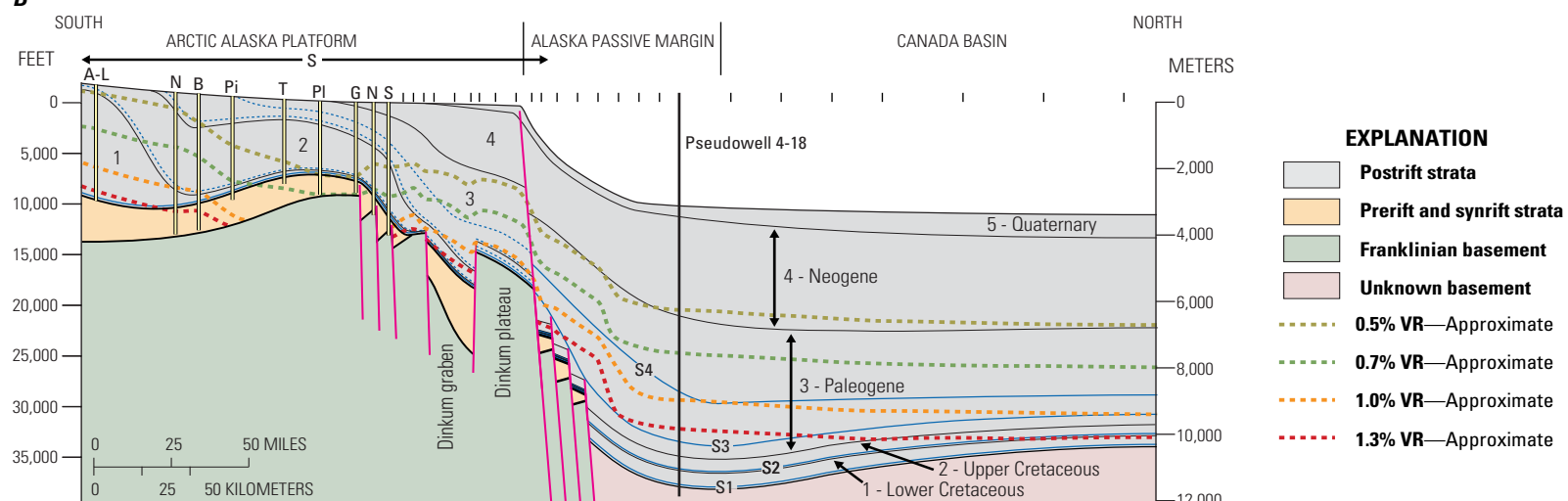

C

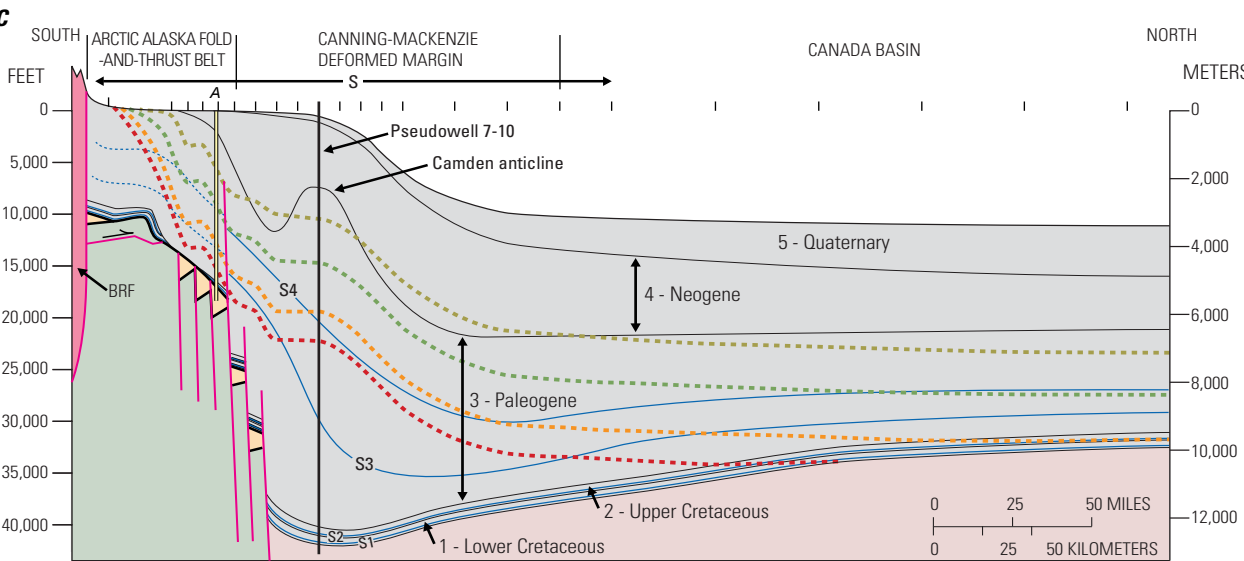

Figure 2. Generalized representative cross sections across the Alaska rift shoulder and southern Canada Basin showing simplified stratigraphy, potential source-rock intervals, and vitrinite reflectance contours resulting from burial-history modeling of exploration wells and pseudowells and use of vitrinite kinetics of Burnham and Sweeney (1989). Boundaries of assessment units are shown by thin vertical lines above each cross section; the Arctic Alaska assessment units are described in Houseknecht and others (2019 [this volume, chap. E]). Locations of pseudowells are shown by black ticks; labeled pseudowells are shown in figures $6,8,9$, and 11 . The following exploration wells are indicated by black-and-yellow lines; A-L, Aufeis and Lupine; N, Nora; B, Bush; Pi, Pipeline; T, Toolik 2; PI, Placid; G, Gwydyr Bay State 1; N, Northstar 1; S, Sandpiper 1; A, Aurora. Potential source-rock intervals shown are S1, Lower Cretaceous; S2, Upper Cretaceous; and S3 and S4, lower and upper limits, respectively, of inferred lower Paleogene interval; S4 represents approximate stratigraphic position of the Azolla horizon documented in ACEX cores on the Lomonosov Ridge. Double-headed arrows labeled " $S$ " show extent of seismic control along each cross section. BRF, Brooks Range front; pink polygon in $\mathrm{C}$ is deeply rooted uplift at front of Brooks Range. Locations of cross sections shown in figures 1,8, and 9 . Cross sections modified from Houseknecht and others (2012b), which describes the constraining data and procedures used in their construction. 


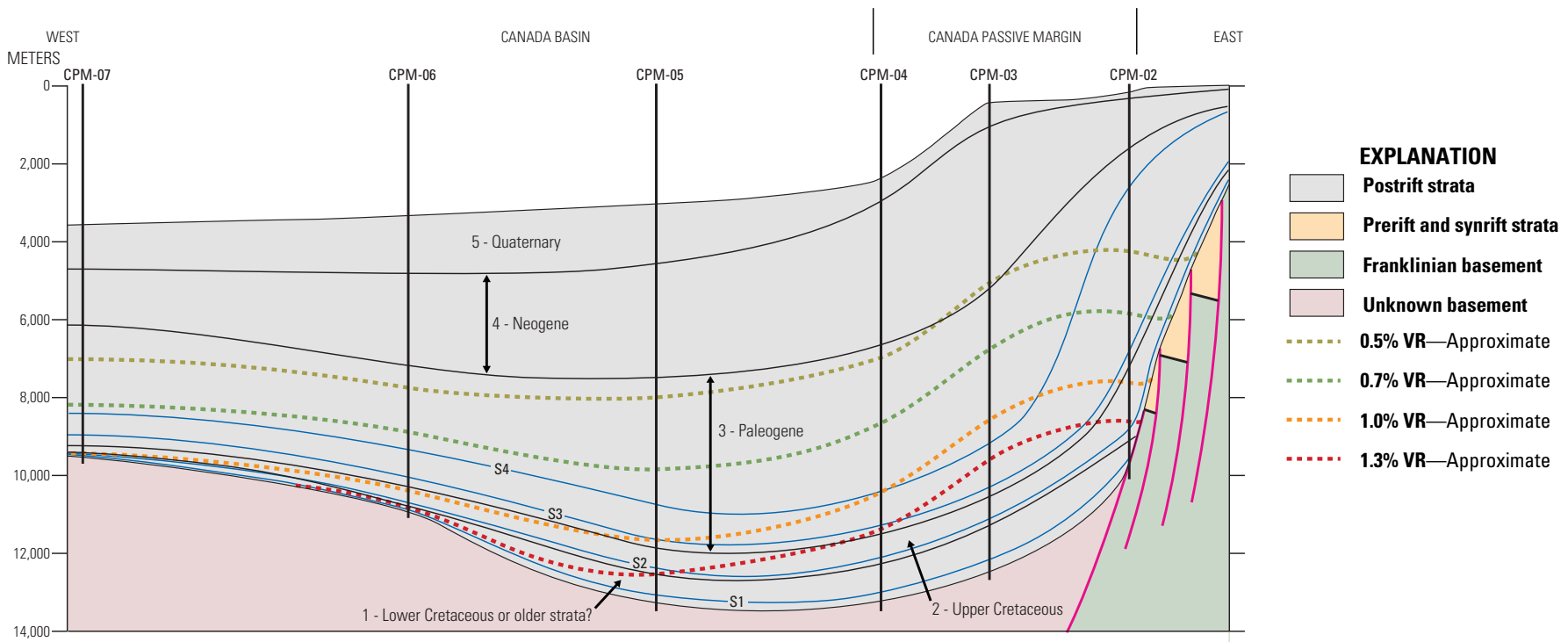

Figure 3. Generalized cross section across the Canada rifted passive margin and extending into the Canada Basin. Boundaries of assessment units are shown by vertical lines above the cross section. Location of cross section shown in figures 1 and 10. Cross section was constructed by using digital bathymetric data, the isopach map of Jackson and Oakey (1990), and known stratigraphy from adjacent regions; however, the lack of direct geologic or seismic data introduces significant uncertainty. Potential source rock intervals shown are S1, Lower Cretaceous; S2, Upper Cretaceous; and S3 and S4, lower and upper limits, respectively, of inferred lower Paleogene interval; S4 represents approximate stratigraphic position of the Azolla horizon documented in ACEX cores on the Lomonosov Ridge. Cross-section construction and thermalmaturity estimation based on procedures described by Houseknecht and others (2012b) for the Alaska margin VR, vitrinite reflectance, in percent (\%).

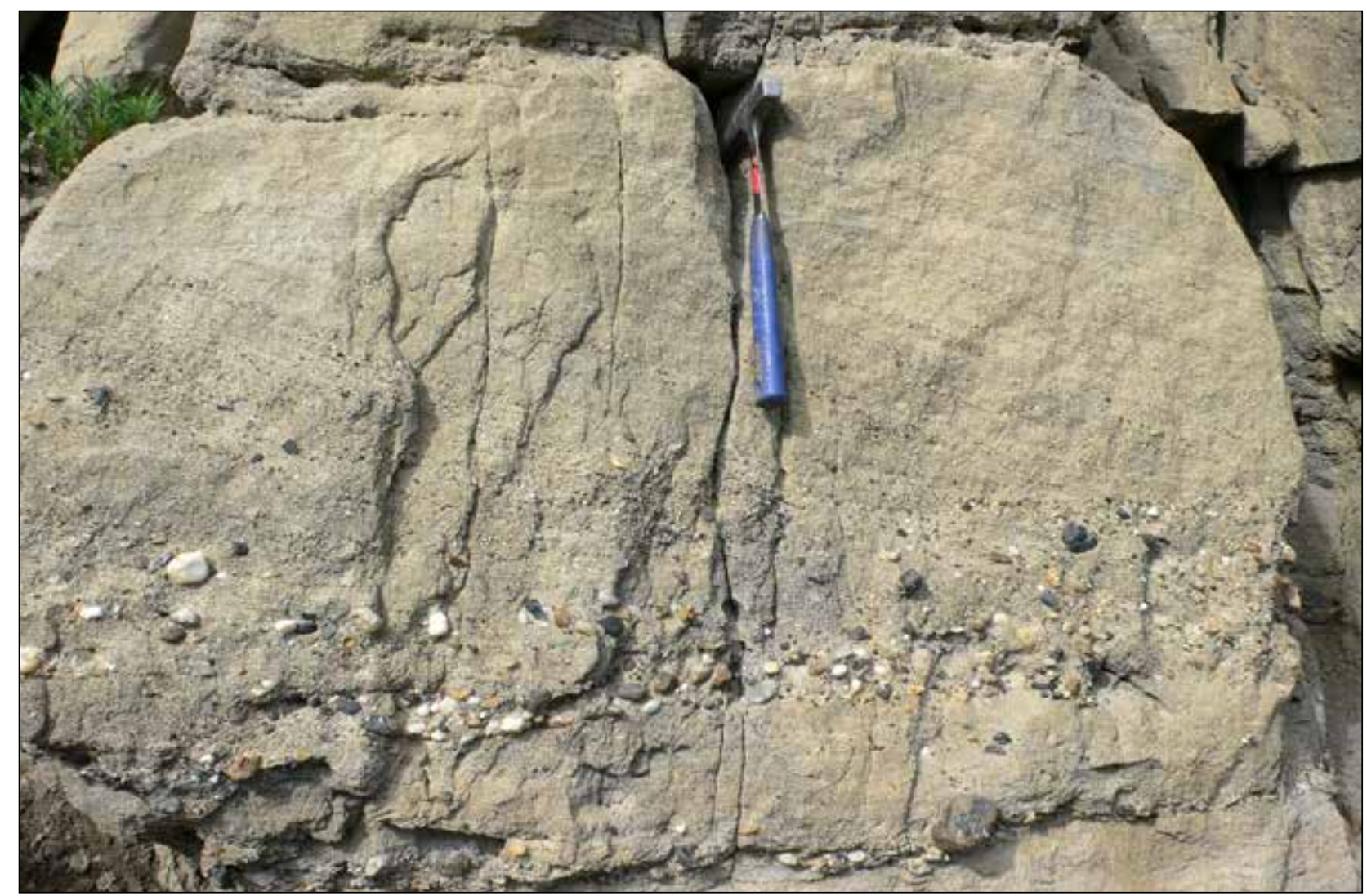

Figure 4. Cross-bedded pebbly sandstone in Paleogene strata exposed along the Sagavanirktok River, Alaska North Slope. This sandstone was deposited in a fluvial system that delivered sediment to the Alaska continental margin of the Amerasia Basin, thus providing insights regarding potential reservoir facies in the Alaska Passive Margin and Canning-Mackenzie Deformed Margin Assessment Units. 


\section{Source-Rock Systems}

Much of the historical oil exploration in Arctic North America, inboard of the hinges, has focused on petroleum systems with Triassic and Jurassic source rocks (Bird, 1985, 2001; Claypool and Magoon, 1985; Magoon and Claypool, 1985; Magoon and others, 1987, 1999, 2003; Magoon, 1994; Bird and Houseknecht, 2011), which are considered to be generally absent outboard of the rift shoulder because the Canada Basin was not yet open when those strata were deposited. Although Triassic and Jurassic strata may be locally present outboard of the rift shoulder in synrift graben basins (Hubbard and others, 1987; Paul and others, 1994), they are buried to depths (more than $10 \mathrm{~km}$ ) that would render any source rocks supramature. Moreover, the preservation potential of any hydrocarbons generated from those strata is considered small. Therefore, analysis of petroleum systems outboard of the hinges is focused on potential source rocks in Cretaceous and younger, postrift strata and is based on indirect evidence from areas adjacent to the Canada Basin. Three stratigraphic intervals appear to have source-rock potential: the succession that includes the lower Cretaceous pebble shale unit (PSU) and gamma-ray zone of the Hue Shale, the lower part of Upper Cretaceous strata, and lower Paleogene strata (Houseknecht and Bird, 2011; Houseknecht and others, 2012b). Each is discussed in a following section.

\section{Lower Cretaceous Source Rocks}

The Lower Cretaceous pebble shale unit (PSU) and gamma-ray zone (GRZ, also known as highly radioactive zone or HRZ) of the Hue Shale (Mull and others, 2003) together represent a condensed section at the base of the Brookian sequence throughout Arctic Alaska (S1 in figs. 2 and 3). These units generally are leaner (lower total organic carbon, TOC) and more gas-prone (lower hydrogen index, $\mathrm{HI}$ ) in the west (Chukchi shelf and western Alaska North Slope) and south (near Brooks Range) and richer (higher TOC) and more oil-prone (higher HI) towards the east and north (rift shoulder) (Peters and others, 2006). Across Arctic Alaska, the PSU and GRZ range from about 1 percent to more than 5 percent TOC, contain a mixture of type II and III kerogen (for definitions of kerogen type, see Tissot and Welte, 1984), and are considered oil-prone over wide areas (Masterson 2001; Peters and others 2006; Houseknecht and Bird, 2011). Approximately coeval strata in Arctic Canada tend to be either lean or gas-prone (Leith and others, 1993; Dixon, 1996; Houseknecht and Bird, 2011). Petroleum accumulations in Arctic Alaska that have been documented to contain oil sourced either exclusively or partly from these basal Brookian source rocks include Endicott, Prudhoe Bay, Lisburne, Point Thomson, and Tarn (Wicks and others 1991; Masterson 2001; Magoon and others, 2003; Peters and others 2008; Houseknecht and others, 2012b).

The age of the PSU and GRZ (Hauterivian-Albian) includes the time interval of Canada Basin extension, which is inferred to have ended no later than Barremian, and of volcanism along the Alpha-Mendeleev igneous province (Grantz and others 2011a). So, even though the Canada Basin was the most distal and deepest marine part of the depositional system in which these strata were deposited, source-rock properties may have been influenced by sea-floor extension in the Canada Basin, by volcanism along the Alpha-Mendeleev volcanic system, and by thermal contraction and subsidence of the rift shoulders along the southern and eastern margins ofthe basin (Houseknecht and Bird, 2011; Houseknecht and others, $2012 b$ ). These processes would most likely have affected the older part of this succession and, therefore, the younger (postBarremian) strata may have the best source-rock potential. On the basis of this line of reasoning, we infer that there is potential for a Lower Cretaceous source rock containing type II kerogen at the base of the postrift section in the Amerasia Basin Province.

\section{Upper Cretaceous Source Rocks}

The lower part of the Upper Cretaceous section (mostly Turonian strata) includes a condensed section that displays source-rock quality in Arctic Alaska (Seabee Formation) and Arctic Canada (Boundary Creek, Smoking Hills, and Kanguk Formations) (S2 in figs. 2 and 3). These formations commonly range from 2 percent to more than 10 percent TOC, contain mostly type II kerogen, and are oil-prone across wide areas (Creaney, 1980; Snowdon 1980; Dixon and others 1992; Dixon 1996; Threlkeld and others 2000; Houseknecht and Bird, 2011). The Seabee and Kanguk Formations are immature beneath the Alaska North Slope and the Arctic Islands, respectively, and have not been inferred as the source of any known oil accumulations. The Boundary Creek-Smoking Hills Formation is inferred to have sourced the Imnak, Mayogiak, Kugpik, and Atkinson oil accumulations in the Mackenzie delta (Snowdon 1980; Dixon 1996).

The widespread occurrence of Turonian source rocks in Arctic Alaska and Canada inboard of the rift shoulders suggests a high probability that coeval source rocks also are present outboard of the rift shoulders. The potential for a source rock containing type II kerogen in the lower part of the Upper Cretaceous section outboard of the rift shoulder is therefore considered likely throughout the Amerasia Basin Province. 


\section{Paleogene Source Rocks}

The lower Paleogene is a condensed section on Lomonosov Ridge, where it was cored in 2004 during the International Ocean Drilling Program Arctic Coring Expedition (ACEX cores, fig. 1). Analyses of ACEX cores suggest the Arctic Ocean was a warm, ice-free, brackish, and bioproductive basin during the early Paleogene (Sluijs and others 2006; Stein and others 2006), a time of globally high temperature and generally high sea level. The ACEX cores include a Paleocene-early middle Eocene succession that is organic rich (TOC mostly $1-5$ percent, up to 14 percent) and that locally contains oil-prone (type II) kerogen (Stein, 2007). Although most of the Paleogene kerogen in the ACEX cores is gas-prone (type III) kerogen, it was deposited before, and during, rifting of the Lomonosov Ridge away from Asia, so it is possible that the kerogen composition reflects dilution by terrigenous organic matter derived from the Asian continent. It is possible that coeval strata in the more distal reaches of the Amerasia Basin, which had fully opened by the Barremian (Grantz and others 1990b, 2011a), may be richer in organic matter and may include oil-prone kerogen. At the top of the organic-rich succession in the ACEX cores, a lowermiddle Eocene Azolla fern horizon occurs, indicating cooler temperatures and probably fresh surface water in the Arctic Ocean (Brinkhuis and others 2006). This Azolla facies is both organic-rich (mostly $2-5$ percent TOC) and oil-prone (Stein, 2007). Thus, evidence from the ACEX cores suggests the potential for organic-rich - and at least partly oil-prone (type II) - kerogen in lower Paleogene strata in the Canada Basin (S3 to S4 in figs. 2 and 3).

Numerous oil occurrences along the Beaufort Shelf of eastern Alaska and in the Mackenzie delta of Canada have been typed to Tertiary-aged kerogen by means of biomarker geochemistry (Magoon and others 1999; Snowdon and others 2004; Houseknecht and others, 2012b), and yet viable source rocks of this age rarely have been penetrated by drilling along the Alaska-Canada margins. It is possible that the widely occurring Tertiary oils were generated from early Paleogene source rocks - likely coeval with those cored on Lomonosov Ridge - that are deeply buried beneath younger Cenozoic strata in the depocenters outboard of the rift shoulders around the southern and eastern margins of the Amerasia Basin Province. Although direct evidence to support this inference is lacking, this potential is considered likely for the purpose of assessing petroleum resources.

Exploration wells have been drilled only in the CanningMackenzie Deformed Margin Assessment Unit (AU) (fig. 1), so there are limited data available regarding the burial history and thermal maturity of strata in the Amerasia Basin Province. Thermal-maturity data from representative wells in the Canning-Mackenzie Deformed Margin AU display generally low gradients of depth versus vitrinite reflectance (fig. 5), a condition that is common on passive continental margins characterized by thick accumulations of overpressured Cenozoic strata. Modeling of the burial and thermal maturation history of that part of the province north of Alaska using cross sections constructed with sparse data (figs. 2 and 3) indicates that most hydrocarbon generation from the three potential source-rock intervals described above (S1, S2, and interval S3-S4 in figs. 2 and 3) occurred during the Paleogene and early Neogene (fig. 6). Earlier generation may have occurred from Lower Cretaceous source rocks in the southwestern part of the Canada Basin (Nuwuk basin of Grantz and others, 1990a), where Early Cretaceous depositional systems overstepped the Alaska rift shoulder (Houseknecht and others, 2009; Houseknecht and Bird, 2011) and deposited a wedge of sediment outboard of the rift shoulder (figs. 2A,7).

Modeling results suggest that the base of the postrift succession grades from supramature (more than 2.6 percent vitrinite reflectance, VR) in the depocenter immediately outboard of the hinge to late mature (1.0-1.3 percent VR) in the northern part of the Canada Basin (fig. 7). Across the same area, the top of the youngest potential source-rock interval (S4 in figs. 2 and 3) grades in a radial pattern from overmature for oil (1.3-2.6 percent VR) in the distal part of the Mackenzie delta depocenter to immature (less than 0.5 percent VR) to early mature $(0.5-0.7$ percent VR) in the western and northern Canada Basin (fig. 7).

Finally, the Amerasia Basin Province undoubtedly contains biogenic gas and gas hydrates in shallow parts of the stratigraphic succession. These resources are not considered in this assessment. 

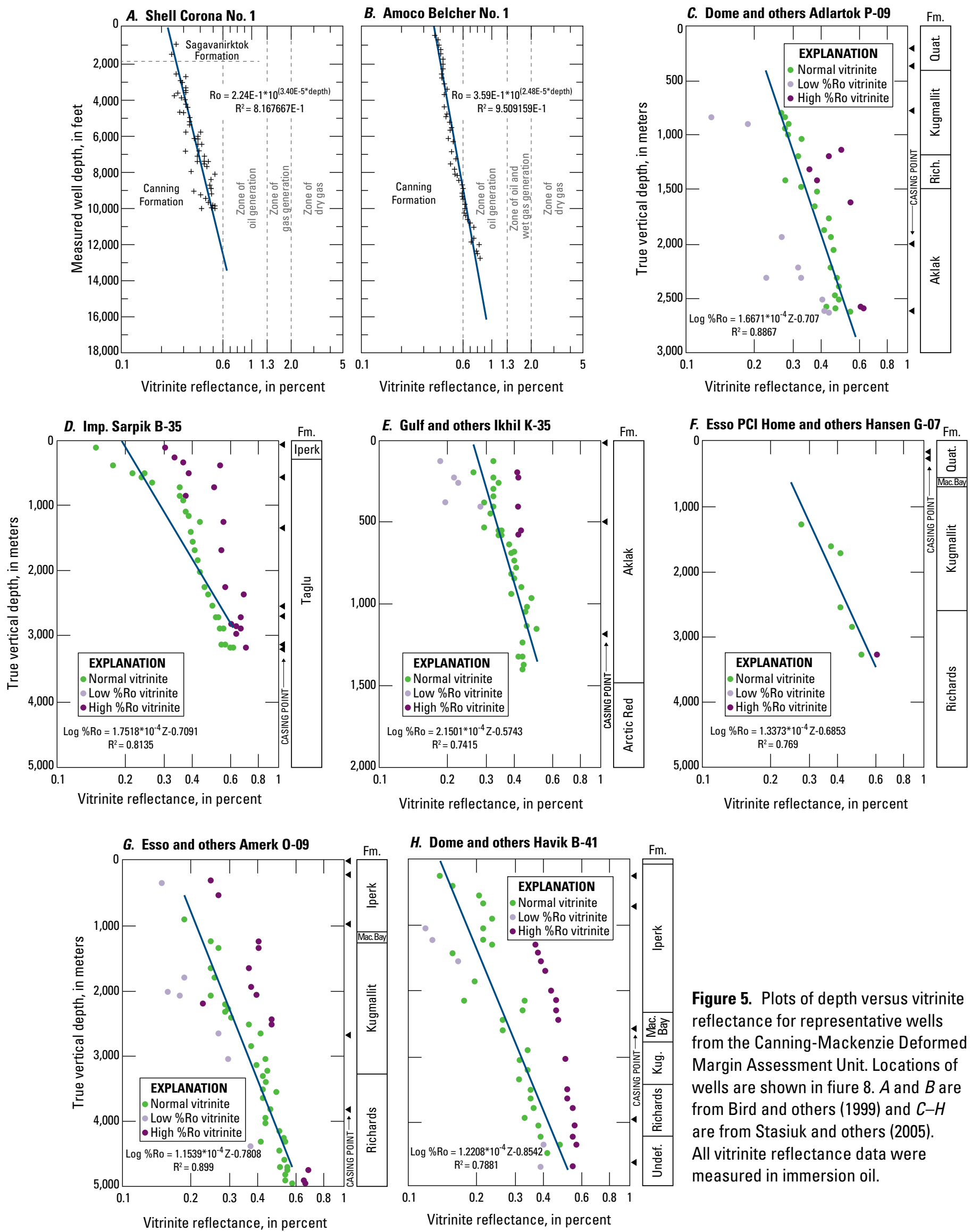

Figure 5. Plots of depth versus vitrinite reflectance for representative wells from the Canning-Mackenzie Deformed Margin Assessment Unit. Locations of wells are shown in fiure 8 . $A$ and $B$ are from Bird and others (1999) and $C-H$ are from Stasiuk and others (2005). All vitrinite reflectance data were measured in immersion oil. 

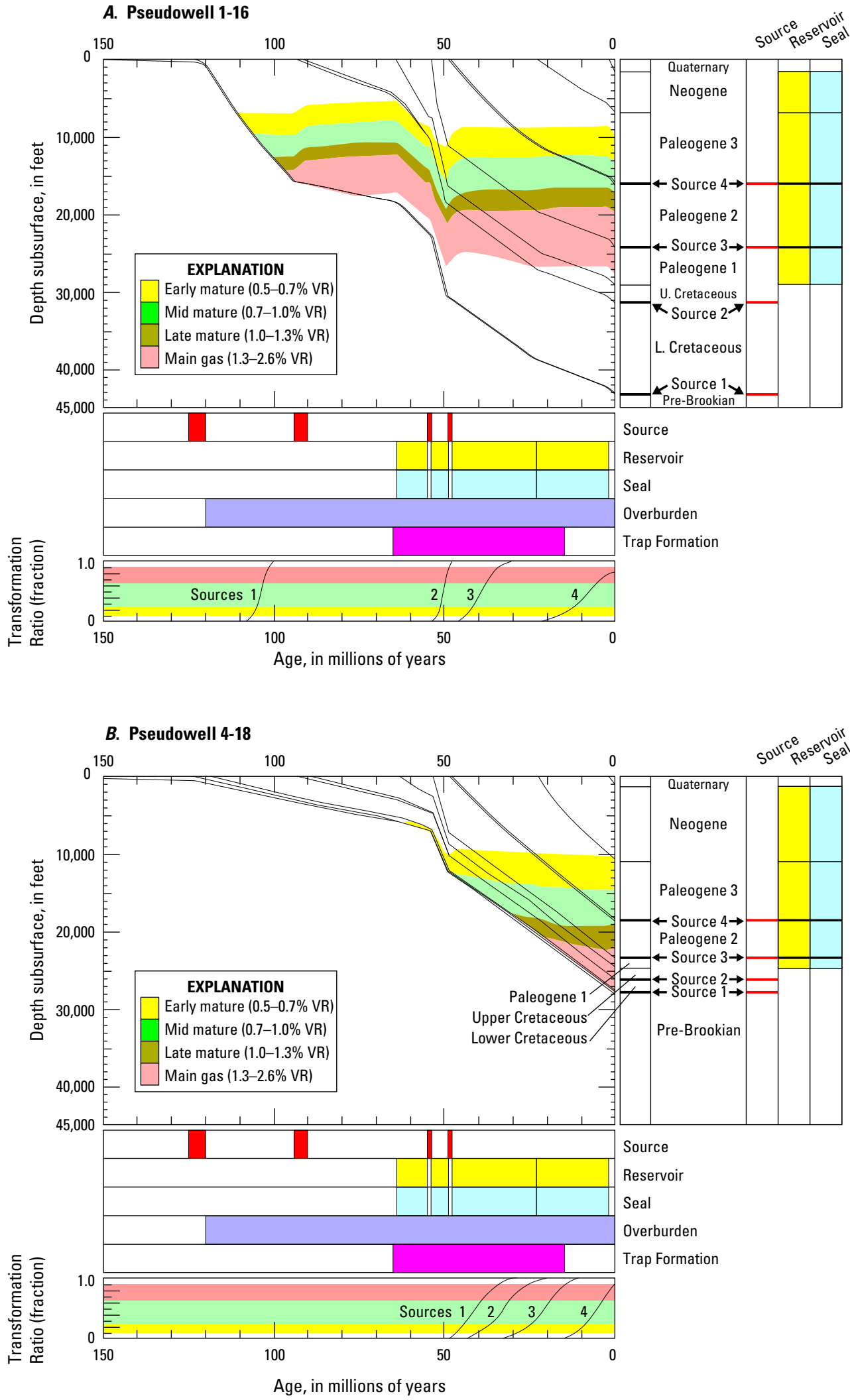

Figure 6. (pages 9-11). Petroleum systems plots for five pseudowells and one well in the Amerasia Basin Province. Locations of pseudowells and wells on maps are shown in figures 1, 8, 9, 10, and 11; locations on cross sections are shown in figures 2 and 3. A, Pseudowell 1-16 in the western part of the Alaska Passive Margin Assessment Unit. $B$, Pseudowell 4-18 in the eastern part of the Alaska Passive Margin Assessment Unit. C, Pseudowell 7-10 in the western part of the Canning-Mackenzie Deformed Margin Assessment Unit. $D$, The Havik B-41 well in the eastern part of the Canning-Mackenzie Deformed Margin Assessment Unit. The upper part of the stratigraphy is based on strata penetrated, and the lower part is based on regional stratigraphic relations. Model constrained by vitrinite-reflectance data from Stasiuk and others (2005). E, Pseudowell CPM-03 in the southern part of the Canada Passive Margin Assessment Unit. F, Pseudowell 7-23 in the deep Canada Basin. $A, B, C$, and $F$ are derived from a regional grid of pseudowells generated for regional modeling (Houseknecht and others, 2012b); $D$ and $E$ are derived from a set of wells and pseudowells modeled by the authors specifically for this assessment using the procedures of Houseknecht and others (2012b) VR, vitrinite reflectance, in percent (\%). 

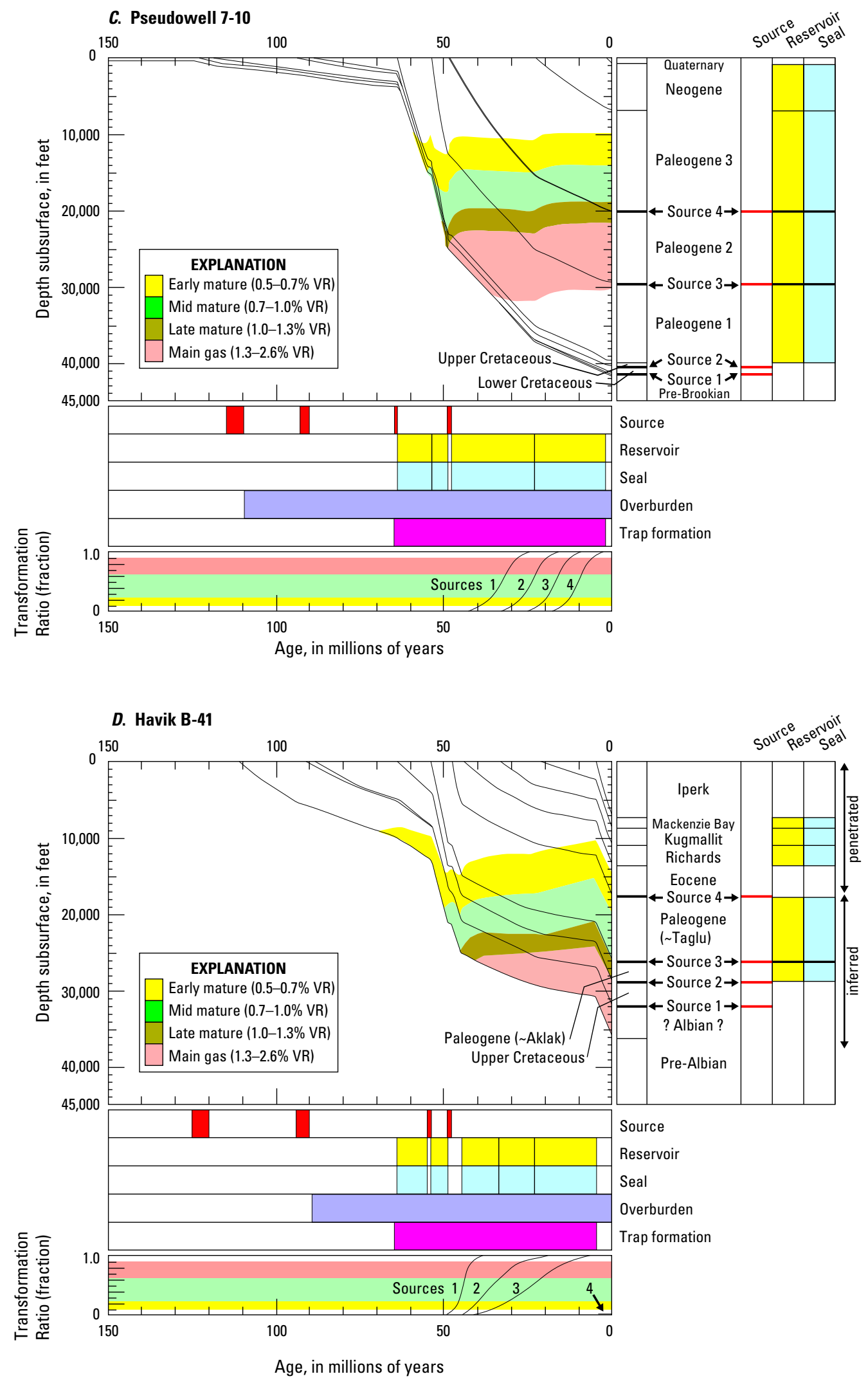

Figure 6. (pages 9-11). - Continued. 

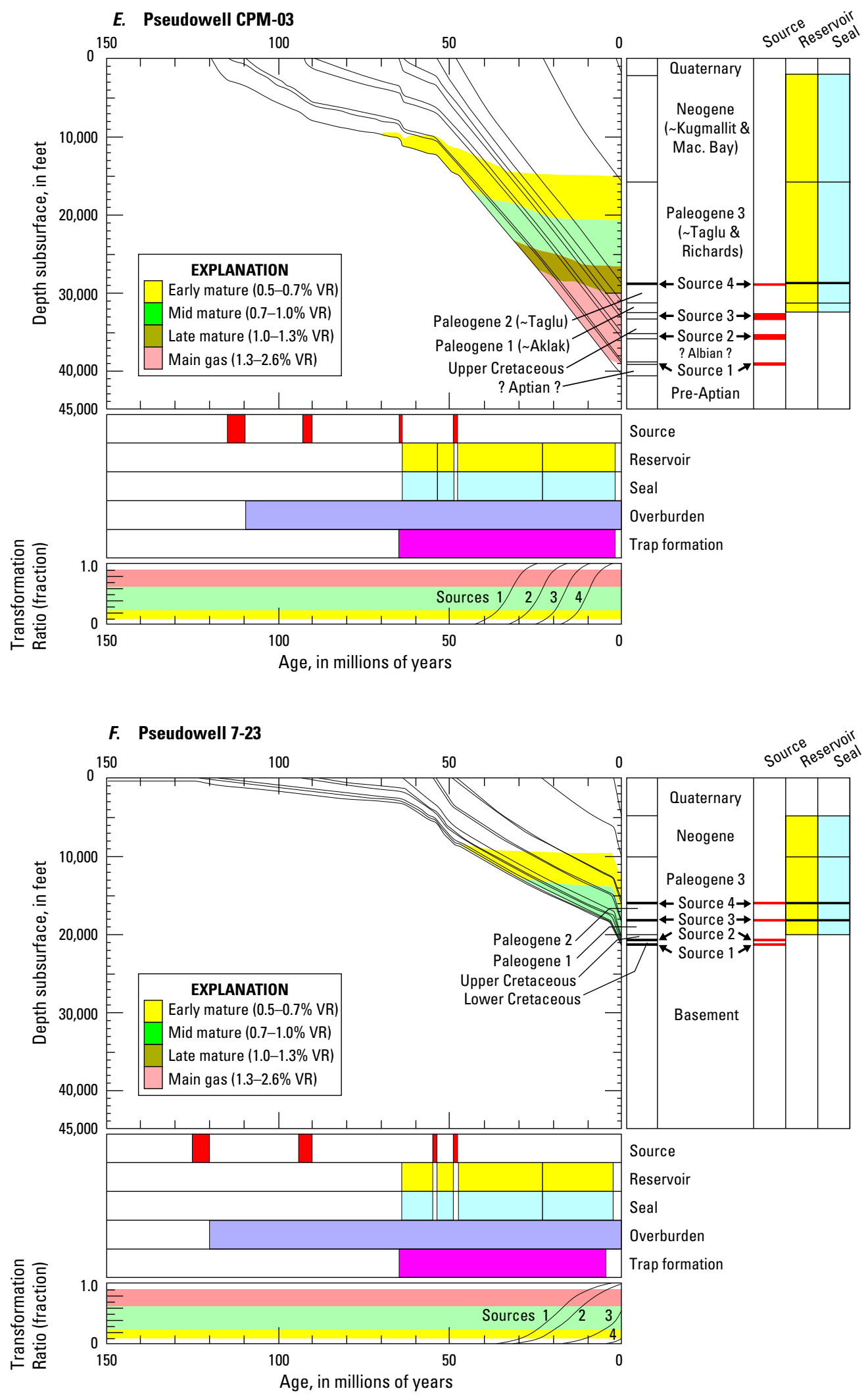

Figure 6. (pages 9-11). - Continued. 

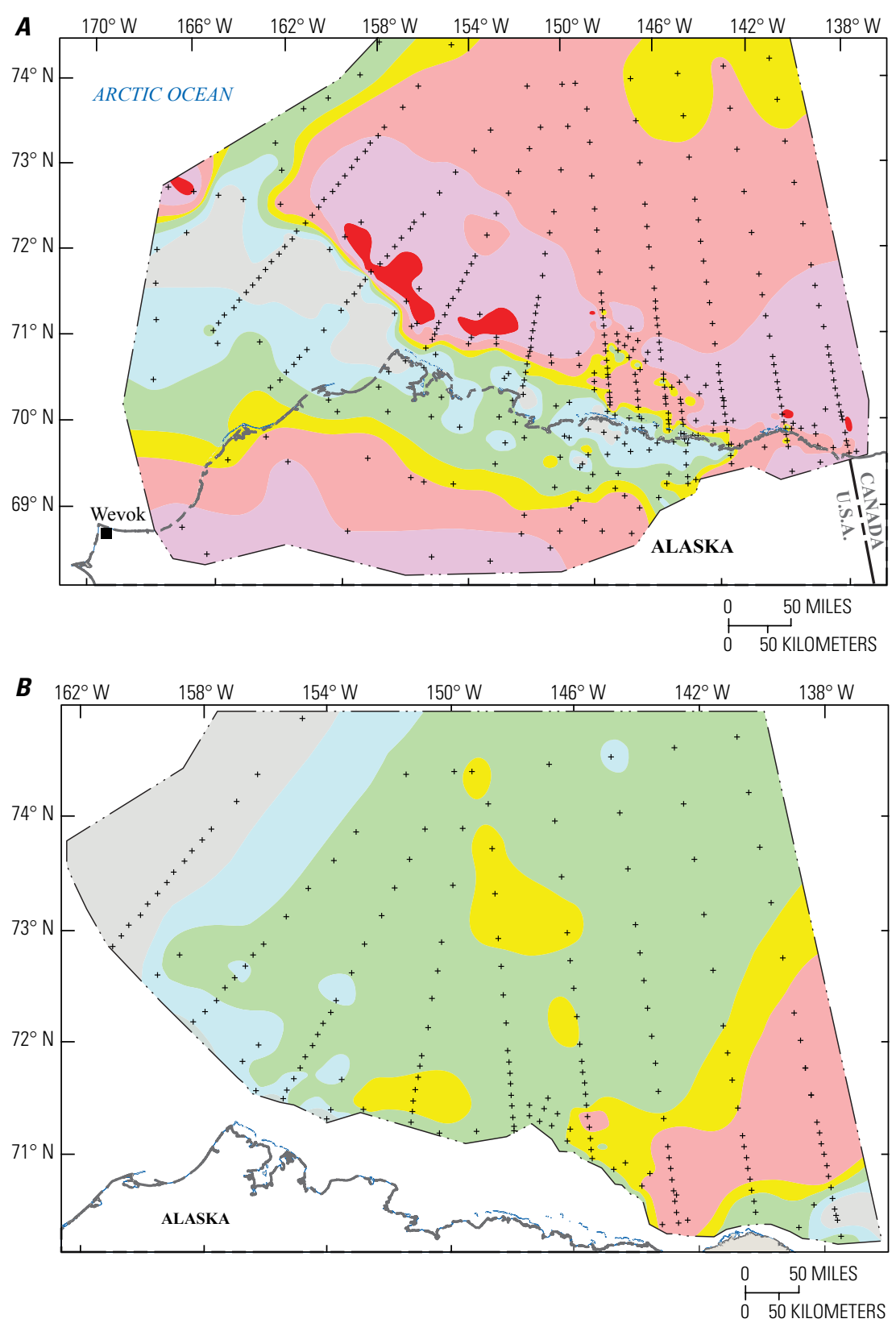

EXPLANATION

Vitrinite reflectance, in percent

$<0.5$

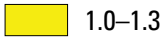

$0.5-0.7$

$1.3-2.6$

$0.7-1.0$

$2.6-5.0$

$>5.0$

Figure 7. Maps of modeled thermal maturity as indicated by ranges of vitrinite reflectance (VR). $A$, Regional map of modeled thermal maturity at the base of the postrift (Brookian) sequence. This map includes most of the Arctic Alaska Province (Houseknecht and others, 2012a; Houseknecht and others, 2019 [this volume]) and the following parts of the Amerasia Basin Province: all of the Alaska Passive Margin AU, the western third of the Canning-Mackenzie Deformed Margin AU, and most of the western and southern parts of the Canada Basin AU. The northwestern margin of the map includes the southeastern part of the Chukchi Borderland (Northwind Ridge). B, Map of modeled thermal maturity at the approximate stratigraphic position of the youngest potential source rock in the Amerasia Basin (approximately lower-middle Eocene Azolla fern facies). Model results in both maps are clipped (dotted and dashed perimeter line) to eliminate contouring edge effects. Both maps are from Houseknecht and others (2012b).

\section{Canning-Mackenzie Deformed Margin Assessment Unit}

The Canning-Mackenzie Deformed Margin AU is the only AU in the Amerasia Basin Province with exploration wells and discovered accumulations, although none of those discovered accumulations has been produced. This level of exploration places the Canning-Mackenzie Deformed Margin AU into uncertainty category 2 on the scale used by the USGS for the Circum-Arctic Resource Appraisal. That scale of uncertainty places each AU into one of five categories based on data density and degree of exploration, as follows: 1, producing fields; 2 , discovered accumulations; 3 , exploration wells; 4, seismic data; and 5, no seismic data (Charpentier and Gautier, 2011).

\section{Assessment Unit Description}

The Canning-Mackenzie Deformed Margin AU extends from the northern margin of the Alaska rift shoulder (hinge) on the south to the limit of contractional folding and faulting within the Cenozoic sediment prism on the north (fig. 8). The western and eastern boundaries of the AU are defined by the lateral limits of contractional deformation associated with ongoing Brooks Range tectonism - the "Canning displacement zone" - on the west (Grantz and others, 1990a) and the "Arctic platform hingeline" on the east (Dixon and Dietrich, 1990). The AU encompasses an area of $97,000 \mathrm{~km}^{2}$. The CanningMackenzie Deformed Margin AU lies mostly on highly extended continental crust that was attenuated during Jurassic to Early Cretaceous rift opening of the Canada Basin; the top of basement lies at great depths (generally more than $10 \mathrm{~km}$ ) 


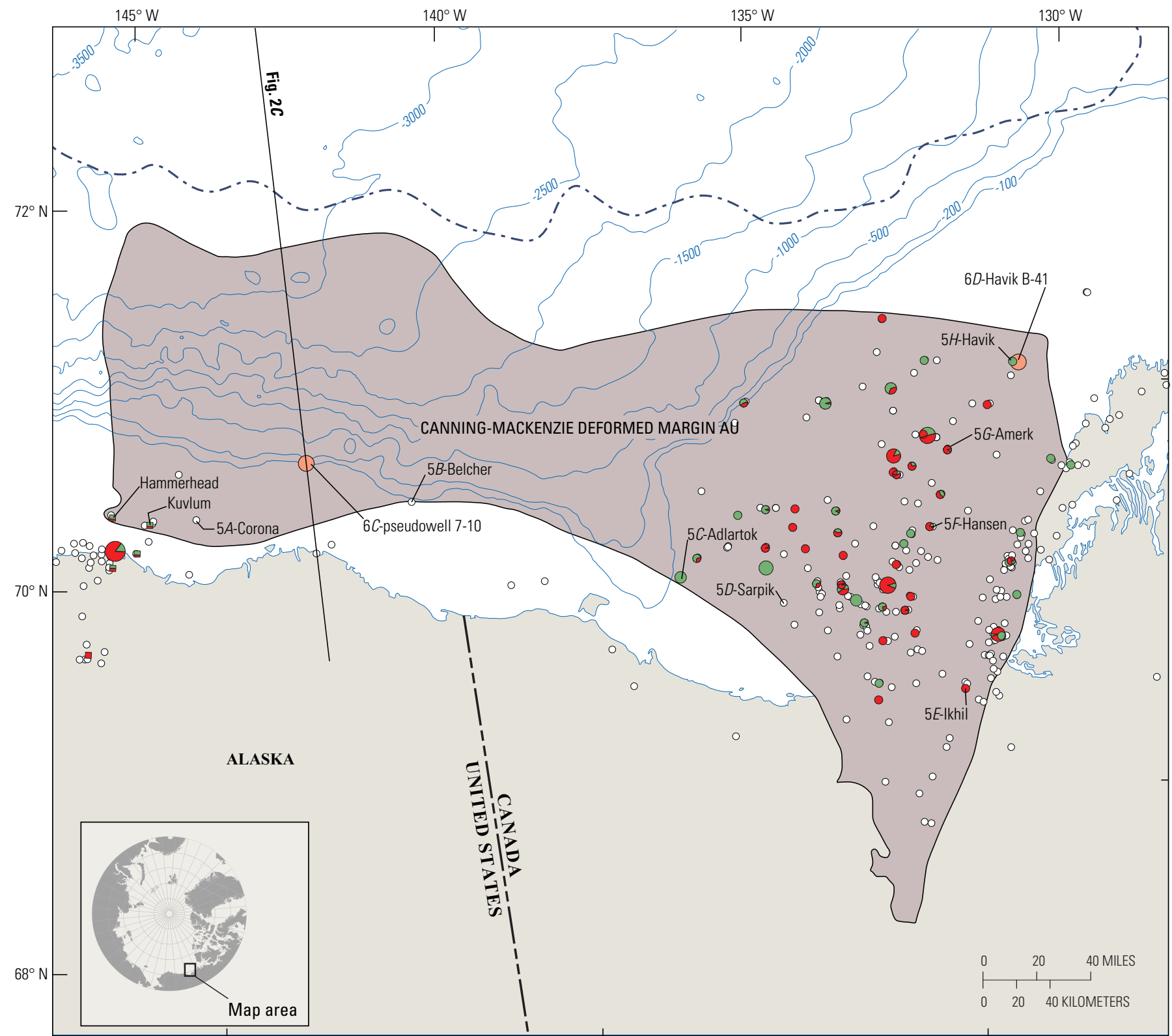

\section{EXPLANATION}

Assessment unit

Median extent of permanent ice-Month of September (1976-2006)

- Exploration well

Location of pseudowells and wells

Bathymetric contour-Interval, in meters, is variable. Datum is sea level

$\boxminus \quad$ Approximate oil/gas (green/red)—Proportion
Accumulation of known size (scale below) showing $\mathbf{o i l} / \mathbf{g a s}$ (green/red)_Proportion based on production and reserves data, in millions of barrels of oil equivalent, $\mathrm{MMBOE}$

$16,384-32,768 \mathrm{MMBOE}$

- 512-1,024 MMBOE

8,192-16,384 MMBOE

256-512 MMBOE

4,096-8,192 MMBOE

128-256 MMBOE

2,048-4,096 MMBOE

- 64-128 MMBOE

1,024-2,048 MMBOE

- $<64$ MMBOE

Figure 8. Map of the Canning-Mackenzie Deformed Margin Assessment Unit showing exploration wells, known petroleum accumulations, line of cross section shown in figure $2 C$, locations of wells for which depth versus vitrinite reflectance data are shown in figure 5, and locations of pseudowells and wells for which petroleum systems plots are shown in figure 6 . 
and cannot be resolved with most available seismic data; an exception is recently collected, deep-resolution seismic data that images the top of acoustic basement (Helwig and others, 2011). The AU is characterized by a thick, growth-faulted, and widely overpressured succession of mostly Cenozoic strata deposited on the rifted margin (Scherr and Johnson, 1998; Hayba and others, 1999). These strata have been deformed by contraction associated with the Brooks Range tectonic front, which has overridden the rift shoulder and propagated northward into the prism of rifted-margin strata (Grantz and others, 1987; Lane, 1998; Lane and Dietrich, 1995; Houseknecht, 2007). Contractional deformation of the Cenozoic sediment prism north of the hinge likely began in the Paleocene and is ongoing, as indicated by active seismicity (Dietrich and Lane, 1992; McMillen and O'Sullivan, 1992; Houseknecht, 2007). Locally, mud diapirism has generated uplift and withdrawal structures and also has modified many contractional structures of tectonic origin. A well-developed gravity fold-and-thrust belt extends from the shelf edge to the toe of the marine slope and includes "fill-and-spill" slope basins (Houseknecht, 2007). Jurassic-Lower Cretaceous synrift and Lower-Upper Cretaceous postrift strata likely are present but are too deeply buried to be exploration objectives except in proximal (southern) parts of the Mackenzie delta.

\section{Geologic Analysis of Assessment Unit Probability}

Although lightly explored, the Canning-Mackenzie Deformed Margin AU contains 14 discovered accumulations larger than 50 MMBOE (million barrels of recoverable oil equivalent), including 2 oil discoveries on the U.S. Beaufort Shelf (Minerals Management Service, 2006; Houseknecht and Bird, 2006) and 8 oil and 4 gas discoveries in the Mackenzie delta (onshore and offshore; Meneley, 1986; National Energy Board, 1998; Osadetz and others, 2005; Johnston, 2007). Moreover, the discovery of numerous oil and gas accumulations smaller than $50 \mathrm{MMBOE}$ in the Mackenzie delta, oil and gas shows in exploration wells throughout the $\mathrm{AU}$, and seeps along the U.S. and Canada coast indicate the presence of an active petroleum system within the AU (Lillis and others, 1999). These indications of a viable petroleum charge, together with the seismically confirmed presence of numerous favorable trap geometries of significant size that have not been tested by drilling (Dixon, 1996; Dixon and others, 1994; Scherr and Johnson, 1998; Osadetz and others, 2005; Helwig and others, 2011), suggest that the probability of at least one undiscovered accumulation of at least $50 \mathrm{MMBOE}$ is 100 percent (appendix 1).

\section{Charge}

Geochemical analysis of oil recovered from wells and seeps confirms the presence of Tertiary source rocks in the $\mathrm{AU}$, and well samples from the Mackenzie delta confirm the local presence of oil- and gas-prone kerogen in carbonaceous shale of Paleogene age (Brooks, 1986a, b; Snowdon, 1987;
Magoon and others, 1999; Snowdon and others, 2004). Although no strata of source-rock quality have been reported from U.S. exploration wells, the recovery from exploration wells and seeps along the U.S. coast of oil geochemically typed to Tertiary source rocks indicates the presence of Tertiary source rocks - probably at depths that have not been penetrated by drilling (Magoon and others, 1999). Paleogene oil- and gas-prone source rocks recovered by scientific drilling on Lomonosov Ridge, together with regional paleogeographic reconstructions (Houseknecht and Bird, 2011; Houseknecht and others, 2012b), suggest that Paleogene source rocks may be present across the entire deepwater parts of the Amerasia Basin.

Geochemistry of produced oil around the southern rim of the Mackenzie delta, together with regional paleogeographic reconstructions, indicates a high probability for the presence of Upper Cretaceous (most likely Turonian) oil-prone source rocks throughout the AU (Snowdon 1980; Dixon and others 1992; Dixon 1996; Threlkeld and others, 2000; unpublished data). Regional tectonic and paleogeographic reconstructions suggest that it also is possible that Jurassic-Lower Cretaceous synrift or early postrift source rocks may be present, at least locally. Although these strata would certainly be overmature today, hydrocarbons generated as those source rocks passed through the oil window may be preserved. Modeling suggests that oil generation likely began during the Paleogene in the Mackenzie delta depocenter, Canadian Beaufort Sea, and easternmost U.S. Beaufort Sea and progressively migrated westward and northward through the Neogene (Houseknecht and others, 2012b).

\section{Rocks}

Proven reservoirs include Paleocene through Oligocene sandstone (Aklak, Taglu, Richards, and Kugmallit Formations in Canada; Canning and Sagavanirktok Formations in the United States). Proven and potential reservoir rocks range from deepwater sediment-gravity-flow and turbidite facies through shallow-marine, deltaic, and perhaps fluvial facies; all these reservoir facies commonly are characterized by lenticular geometry (Molenaar, 1983; Dixon and others, 1992; Dixon, 1996; Scherr and Johnson, 1998). Significant stratigraphic thickening across growth faults is common. Seals include shale and mudstone in the Paleocene through Oligocene succession, and seal integrity and capacity are demonstrated by a large number of discovered oil and gas accumulations. Discovered accumulations have been found in structural, combination, and stratigraphic traps (Meneley, 1986; Enachescu, 1990; Dixon, 1996; Scherr and Johnson, 1998). The largest discovered accumulations and the potential for undiscovered accumulations larger than 50 MMBOE mostly are associated with contractional anticlines in which reservoir volume and geometry are influenced by growth faults and facies lenticularity. However, a spectrum of trap types is present and includes closures associated with tectonic, gravity, and diapiric anticlines; tectonic and gravity thrust faults; growth faults; localized withdrawal and slope basins; and a variety of lenticular sandstone facies (see, for example, Bergquist and others, 2003). 


\section{Timing and Preservation}

Modeling suggests that oil generation began in the Mackenzie delta depocenter during the Paleocene and radiated outward to the west and north during the Eocene through Holocene as thick, progressively offlapping sequences were deposited. Much contractional structuring was syndepositional or early postdepositional. Thus, timing was excellent for early charging of relatively young reservoirs in both structural and stratigraphic traps. The potential for preservation of reservoired hydrocarbons also is considered excellent, as indicated by the large number of discovered accumulations. Ongoing contractional deformation, indicated by active seismicity, may indicate the local potential for trap disruption and leakage of hydrocarbons.

\section{Analogs Used for Assessment}

Assessment input was influenced by the geology, size, and number of discovered accumulations in the $\mathrm{AU}$ and by the assessments of undiscovered resources conducted by the Minerals Management Service (MMS) (Scherr and Johnson, 1998; Minerals Management Service, 2006) and the Geological Survey of Canada (GSC) (Dixon and others, 1994; Chen and others, 2007), which were largely based on the mapping of favorable trap geometries from seismic data. Analogs were selected from the USGS World Analog Database (Charpentier and others, 2008) in two stages: (1) a two-tier search of rifted passive margin architecture plus compressional structural setting and (2) a combined search of trap systems comprising compressional anticlines, folds, and thrusts developed on transitional to oceanic basement plus delta trap systems. The resulting analog set was culled to eliminate salt structures, basement-involved block structures, and other geologic parameters judged to be inappropriate for this AU. The final analog set consists of 34 AUs (table 1).

\section{Asessment Inputs}

\section{Number of Accumulations}

Considering the lightly explored nature of this $\mathrm{AU}$, a minimum number of 15 accumulations of at least $50 \mathrm{MMBOE}$ was selected because that approximately equals the 14 discovered accumulations of at least 50 MMBOE. The analog set displays a fairly uniform distribution of accumulation density up to about 1.5 accumulations larger than $50 \mathrm{MMBOE} / 1,000 \mathrm{~km}^{2}$, with a single outlier at 2.4. Considering that 14 accumulations greater than the minimum size have been discovered, input values of 15 ( 0.15 density) at the minimum, 40 ( 0.40 density) at the median, and 125 (1.26 density) at the maximum were selected (appendix 1).

\section{Oil-to-Gas Mix}

The minimum, median, and maximum values of the oilto-gas ratio were set at $0.4,0.7$, and 0.8 (appendix 1) on the basis of the ratio of oil/gas accumulations in the discovered population (larger than $50 \mathrm{MMBOE}$ ) and geologic reasoning regarding the spatial distribution of oil- versus gas-prone source rocks across the AU.

\section{Accumulation Size Distribution}

The median oil accumulation size was set at $125 \mathrm{MMBO}$ (appendix 1) on the basis of sizes of discovered accumulations in the AU; this value also closely matches the median and mean values of the median accumulation size in the analog set. The maximum oil accumulation size was set at $5 \mathrm{BBO}$ (billion barrels of recoverable oil; appendix 1) on the basis of size of the largest untested structures and the size of the largest known accumulations in the analog population, which is between 5 and $6 \mathrm{BBO}$. Median and maximum input values of $600 \mathrm{BCF}$ (billion cubic feet of recoverable gas) and $15 \mathrm{TCF}$ (trillion cubic feet of recoverable gas) were set for gas accumulation sizes by the same line of reasoning (appendix 1).

\section{Estimated Maximum Accumulation Size}

Maximum accumulation sizes of about $1 \mathrm{BBO}$ and 2 to $3 \mathrm{TCFG}$ were selected on the basis of size distribution of discovered accumulations, the largest accumulation sizes assessed by MMS and GSC using a large seismic database to constrain trap sizes, and analysis of seismic and well data available to the USGS. These maximum sizes, which did not enter directly into the volumetric calculations, were used to judge the reasonableness of the results of statistical analysis.

\section{Ancillary Properties and Co-Product Ratios}

Data from discovered pools in this AU and from geochemistry of source rocks were used to establish input values for these parameters.

\section{Results}

Probabilistic estimates of volumes of undiscovered, technically recoverable hydrocarbons for the CanningMackenzie AU are summarized in table 2. These results include mean estimates of more than $6 \mathrm{BBO}$, nearly $20 \mathrm{TCF}$ associated gas, and $16 \mathrm{TCF}$ nonassociated gas. 
Table 1. Analog assessment units used to constrain input parameters for the Canning-Mackenzie Deformed Margin Assessment Unit. Analog data from Charpentier and others (2008).

[AU, assessment unit; TPS, total petroleum system]

\begin{tabular}{|c|c|c|c|}
\hline AU Code & AU name & TPS name & Province name \\
\hline 11120101 & Apsheron-Pribalkhan Zone & Oligocene-Miocene Maykop/Diatom & South Caspian Basin \\
\hline 11120102 & Lower Kura Depression and Adjacent Shelf & Oligocene-Miocene Maykop/Diatom & South Caspian Basin \\
\hline 11120103 & Gograndag-Okarem Zone and Adjacent Shelf & Oligocene-Miocene Maykop/Diatom & South Caspian Basin \\
\hline 11120104 & Central Offshore & Oligocene-Miocene Maykop/Diatom & South Caspian Basin \\
\hline 11120105 & Iran Onshore/Nearshore & Oligocene-Miocene Maykop/Diatom & South Caspian Basin \\
\hline 20160201 & Natih-Fiqa Structural/Stratigraphic & Middle Cretaceous Natih & Fahud Salt Basin \\
\hline 20230202 & Basinal Oil and Gas & Jurassic Gotnia/Barsarin/Sargelu/Najmah & Widyan Basin-Interior Platform \\
\hline 20480101 & Bou Dabbous-Tertiary Structural/Stratigraphic & Bou Dabbous-Tertiary & Pelagian Basin \\
\hline 20480201 & Jurassic-Cretaceous Structural/Stratigraphic & Jurassic-Cretaceous Composite & Pelagian Basin \\
\hline 37010101 & Brunei-Sabah Deltaics & Brunei-Sabah & Baram Delta/Brunei-Sabah Basin \\
\hline 37010102 & Brunei-Sabah Turbidites & Brunei-Sabah & Baram Delta/Brunei-Sabah Basin \\
\hline 38170101 & Kutei Basin Deltaics & Kutei Basin & Kutei Basin \\
\hline 38170102 & Kutei Basin Turbidites & Kutei Basin & Kutei Basin \\
\hline 38170103 & Kutei Basin Fold and Thrust Belt & Kutei Basin & Kutei Basin \\
\hline 39100201 & Petrel & Keyling/Hyland Bay-Permian & Bonaparte Gulf Basin \\
\hline 39100301 & Malita & Jurassic/Early Cretaceous-Mesozoic & Bonaparte Gulf Basin \\
\hline 60210101 & Late Cretaceous-Tertiary Turbidites & Cenomanian-Turonian & Guyana-Suriname Basin \\
\hline 60220101 & Amazon Delta and Submarine Fan & Neogene & Foz do Amazonas Basin \\
\hline 60340103 & Abrolhos Sub-Volcanic Structures & Cretaceous Composite & Espirito Santo Basin \\
\hline 60370101 & Pelotas Platform and Basin & Cenomanian-Turonian-Tertiary Composite & Pelotas Basin \\
\hline 60410101 & Hollin-Napo & Mesozoic-Cenozoic & $\begin{array}{l}\text { Putumayo-Oriente- Maranon } \\
\text { Basin }\end{array}$ \\
\hline 60980201 & Trinidad Basins & Upper Cretaceous/Tertiary & East Venezuela Basin \\
\hline 61030101 & Carupano Basin Gas & Lower Cruse & Tobago Trough \\
\hline 61070101 & Inner Forearc Deformation Belt & Tobago Trough Paleogene & Lesser Antilles DeformedBelt \\
\hline 71920101 & Agbada Reservoirs & Tertiary Niger Delta (Agbada/Akata) & Niger Delta \\
\hline 71920102 & Akata Reservoirs & Tertiary Niger Delta (Agbada/Akata) & Niger Delta \\
\hline 72030301 & Central Congo Delta and Carbonate Platform & Congo Delta Composite & West-Central Coastal \\
\hline 72030302 & Central Congo Turbidites & Congo Delta Composite & West-Central Coastal \\
\hline 72030401 & Cuanza-Namibe & Cuanza Composite & West-Central Coastal \\
\hline 73030101 & Offshore & Cretaceous Composite & Orange River Coastal \\
\hline 80420102 & Indus Fan & Sembar-Goru/Ghazij & Indus \\
\hline 80470302 & Eastern Fold Belt & Jenam/Bhuban-Bokabil & Ganges-Brahmaputra Delta \\
\hline 80480101 & Central Burma Basin & Eocene to Miocene Composite & Irrawaddy \\
\hline 80480102 & Irrawaddy-Andaman & Eocene to Miocene Composite & Irrawaddy \\
\hline
\end{tabular}


Table 2. Summary of results for risked, undiscovered, technically recoverable petroleum resources for the Amerasia Basin Province, including results for the Canning-Mackenzie Deformed Margin, Alaska Passive Margin, Canada Basin, and Canada Passive Margin Assessment Units.

[F95 represents a 95-percent chance of at least the amount tabulated; other fractiles are defined similarly. Std. dev., standard deviation. Because the assessment unit probability for the Canada Basin was less than 0.1, the unit was not quantitatively assessed, and no statistical results are listed below.]

\begin{tabular}{|c|c|c|c|c|c|}
\hline \multicolumn{3}{|c|}{ Assessment unit name } & \multicolumn{3}{|c|}{ Assessment unit probability } \\
\hline \multicolumn{3}{|c|}{ Canning-Mackenzie Deformed Margin } & \multicolumn{3}{|c|}{1.000} \\
\hline \multicolumn{3}{|l|}{ Alaska Passive Margin } & \multicolumn{3}{|c|}{0.540} \\
\hline \multicolumn{3}{|l|}{ Canada Basin } & \multicolumn{3}{|c|}{0.050} \\
\hline \multicolumn{3}{|l|}{ Canada Passive Margin } & \multicolumn{3}{|c|}{0.540} \\
\hline Assessment unit name & F95 & F50 & F5 & Mean & Std. dev. \\
\hline \multicolumn{6}{|c|}{ Oil, in millions of barrels (MMBO) } \\
\hline $\begin{array}{l}\text { Canning-Mackenzie } \\
\text { Deformed Margin }\end{array}$ & $2,518.34$ & $5,697.36$ & $12,566.69$ & $6,380.64$ & $3,230.00$ \\
\hline Alaska Passive Margin & 0.00 & 886.94 & $2,900.42$ & 972.23 & $1,062.11$ \\
\hline Canada Passive Margin & 0.00 & $1,760.64$ & $7,718.95$ & $2,370.71$ & $2,840.77$ \\
\hline \multicolumn{6}{|c|}{ Associated/dissolved gas, in billions of cubic feet (BCFG) } \\
\hline $\begin{array}{l}\text { Canning-Mackenzie } \\
\text { Deformed Margin }\end{array}$ & $7,146.42$ & $17,229.69$ & $41,198.11$ & $19,799.52$ & $11,026.40$ \\
\hline Alaska Passive Margin & 0.00 & $2,463.67$ & $9,391.56$ & 3,021.03 & $3,423.24$ \\
\hline Canada Passive Marginn & 0.00 & $5,127.64$ & $24,410.54$ & $7,348.82$ & $8,922.70$ \\
\hline \multicolumn{6}{|c|}{ Natural gas liquids, in millions of barrels (MMBNGL) } \\
\hline $\begin{array}{l}\text { Canning-Mackenzie } \\
\text { Deformed Margin }\end{array}$ & 48.85 & 126.32 & 325.67 & 148.99 & 93.86 \\
\hline Alaska Passive Margin & 0.00 & 16.42 & 73.71 & 22.71 & 27.10 \\
\hline Canada Passive Margin & 0.00 & 35.50 & 187.39 & 55.27 & 68.55 \\
\hline \multicolumn{6}{|c|}{ Nonassociated gas, in billions of cubic feet (BCFG) } \\
\hline $\begin{array}{l}\text { Canning-Mackenzie } \\
\text { Deformed Margin }\end{array}$ & $5,661.40$ & $13,867.14$ & $34,298.55$ & $16,102.74$ & $9,339.49$ \\
\hline Alaska Passive Margin & 0.00 & $1,850.38$ & $9,676.02$ & $2,866.13$ & $3,509.58$ \\
\hline Canada Passive Margin & 0.00 & $3,995.34$ & $28,482.78$ & $7,752.97$ & $10,659.14$ \\
\hline \multicolumn{6}{|c|}{ Liquids, in millions of barrels (MMBL) } \\
\hline $\begin{array}{l}\text { Canning-Mackenzie } \\
\text { Deformed Margin }\end{array}$ & 60.70 & 160.86 & 417.14 & 189.54 & 117.40 \\
\hline Alaska Passive Margin & 0.00 & 18.99 & 118.84 & 33.68 & 43.12 \\
\hline Canada Passive Margin & 0.00 & 42.90 & 341.53 & 91.52 & 127.61 \\
\hline \multicolumn{6}{|c|}{ Largest oil, in millions of barrels (MMB0) } \\
\hline $\begin{array}{l}\text { Canning-Mackenzie } \\
\text { Deformed Margin }\end{array}$ & 401.66 & $1,074.64$ & $3,233.84$ & $1,332.88$ & 886.38 \\
\hline Alaska Passive Margin & 150.76 & 286.43 & 647.56 & 325.87 & 155.39 \\
\hline Canada Passive Margin & 219.78 & 369.63 & 645.30 & 391.65 & 128.36 \\
\hline
\end{tabular}




\section{Alaska Passive Margin Assessment Unit}

The Alaska Passive Margin AU contains no exploration wells and only sparse seismic data. This level of exploration places the Alaska Passive Margin into uncertainty category 4 on the scale used by the USGS for the Circum-Arctic Resource Appraisal (Charpentier and Gautier, 2011).

\section{Assessment Unit Description}

The Alaska Passive Margin AU extends from the northern margin (hinge) of the Alaska rift shoulder on the south to the approximate base of the Beaufort Sea marine slope (about 3,500 $\mathrm{m}$ water depth), which is inferred to be the northward limit of gravity folding and slumping (fig. 9). The western boundary of the AU is defined by the eastern margin of the Chukchi Borderland. The eastern boundary of the AU is defined by the Canning displacement zone (Grantz and others, 1990b), an active left-lateral zone of displacement that defines the western limit of the Canning-Mackenzie Deformed Margin AU. The AU encompasses an area of $93,000 \mathrm{~km}^{2}$.

The Alaska Passive Margin AU lies mostly on extended continental crust that was attenuated during Jurassic-Early Cretaceous rift opening of the Canada Basin. The top of basement lies at great depths (generally more than $10 \mathrm{~km}$ ) and cannot be resolved with available seismic data. The AU is characterized by a thick, growth-faulted, and probably overpressured succession of mostly Cenozoic strata deposited on the rifted margin. Cretaceous (and perhaps Jurassic) strata likely are present but are buried beneath such a great thickness of Cenozoic strata that they cannot be identified in seismic data and are unlikely to be oil or gas prospective. In particular, a thick succession of Lower Cretaceous strata is assumed to be present just north of the hinge (fig. $2 A$ ) on the basis of seismic evidence that Early Cretaceous depositional systems overstepped the rift shoulder along the northeast margin of the Chukchi shelf (Houseknecht and others, 2009). The presence of a gravity fold belt beneath the marine slope is suggested by seismic imaging of large-displacement listric growth faults beneath the outer shelf, normal faults that offset the seafloor at the shelf margin, and detachment folds in the upper part of the Cenozoic sediment prism beneath the upper slope. However, the presence of a gravity fold system beneath most of the marine slope cannot be confirmed because no seismic data are available beyond the uppermost slope.

\section{Geologic Analysis of Assessment Unit Probability}

Even though no exploration wells have been drilled in the Alaska Passive Margin AU, available evidence suggests a generally favorable probability for the presence of at least one accumulation of at least $50 \mathrm{MMBOE}$ (appendix 2). Charge is viewed as the greatest risk factor.

\section{Charge}

There is no direct evidence of an active petroleum system in the Alaska Passive Margin AU. To the east, an active petroleum system is present in the Canning-Mackenzie Deformed Margin AU, with confirmed Tertiary oil in two discoveries of at least 50 MMBO (Hammerhead and Kuvlum, fig. 9) (Scherr and Johnson, 1998; Minerals Management Service, 2006; Houseknecht and Bird, 2006) a short distance east of the AU and in numerous shows in exploration wells and seeps along the coast (Houseknecht and others, 2012b). Paleogene oil- and gas-prone source rocks recovered by scientific drilling on Lomonosov Ridge suggest that source rocks may be present across the entire Amerasia Basin. This inference is supported by palynological data indicating the presence of the Azolla fern facies in two wells (Popcorn and Crackerjack) (Jonathan P. Bujak, Bujak Research International, written commun., 2007) in the northern part of the Chukchi shelf, although the mudstone in which the Azolla facies occurs is not of source-rock quality in those two wells. Regional tectonic and paleogeographic reconstructions suggest that it also is likely that Jurassic-Lower Cretaceous synrift and Lower-Upper Cretaceous post rift source rocks may be present in the AU. Although these strata would certainly be overmature today, hydrocarbons generated as those source rocks were buried through the oil window may be preserved. Modeling suggests that oil generation likely began during the Early Cretaceous and progressively migrated eastward and northward through the Late Cretaceous and Tertiary (Houseknecht and others, 2012b). On the basis of this mostly circumstantial evidence, yet regionally favorable prognosis, a charge probability of 0.6 is assigned to this AU (appendix 2).

\section{Rocks}

Even though seismic data demonstrate the presence of more than $10 \mathrm{~km}$ of growth-faulted strata along the southern margin of this $\mathrm{AU}$, the exact age of those strata is unknown (because no wells exist to provide age constraints), and seismic correlation across large-displacement growth faults is not possible. Regional relations suggest that most of this succession is Paleocene and younger and that it is composed of mostly mudstone and sandstone. On the basis of seismic similarities and apparent continuity of depositional sequences from the Chukchi shelf to the south and from the Beaufort Shelf to the east, these strata probably include good reservoirquality sandstone and seal-quality mudstone. The largest potential traps observed in seismic data are large-displacement (hundreds of meters) growth-fault systems. Smaller potential traps may include low-stand, shelf-margin truncations and channelized facies in both deepwater and shallow-water facies. A rock probability of 0.9 (appendix 2) is assigned on the basis of these generally favorable parameters. 


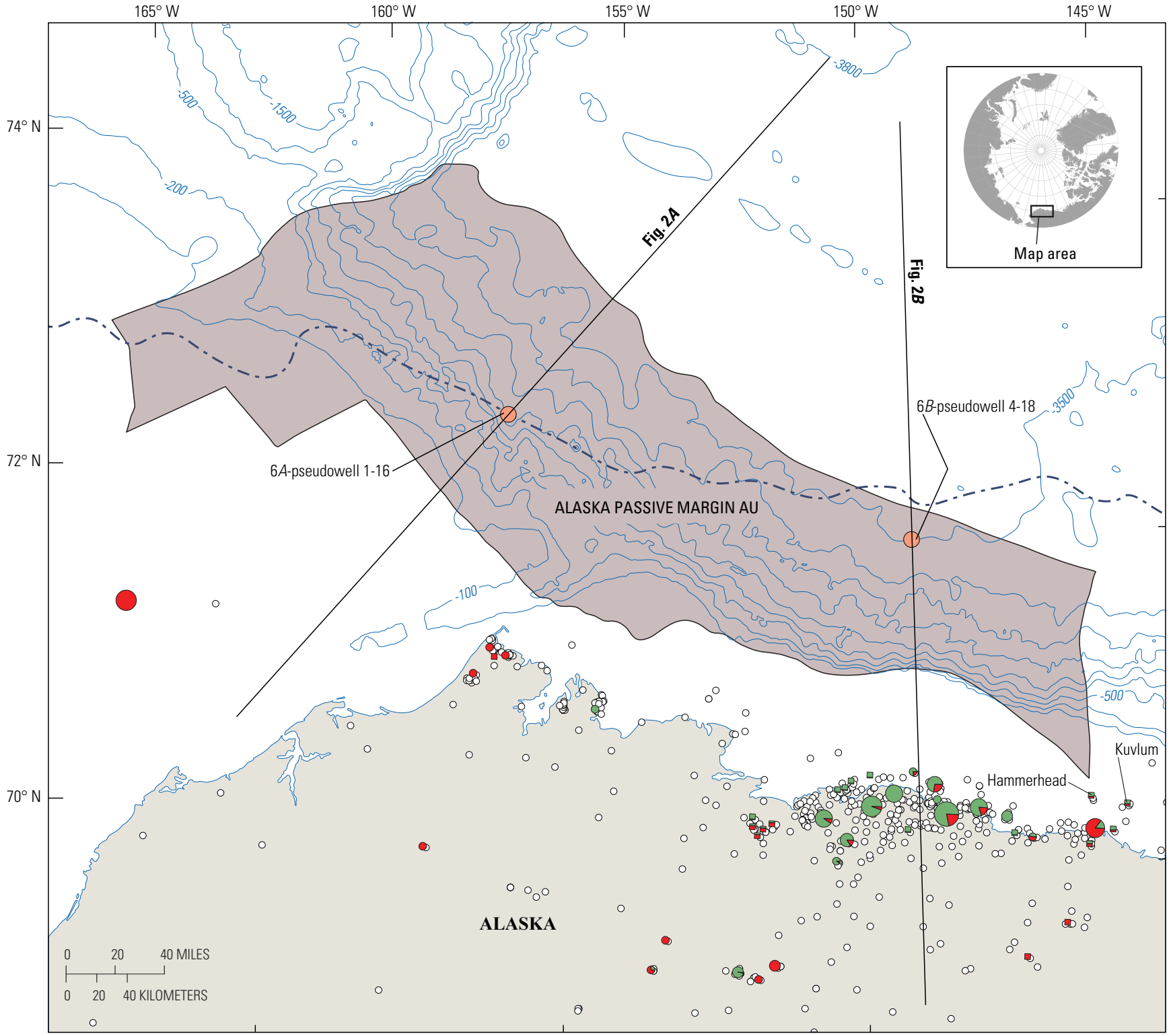

EXPLANATION

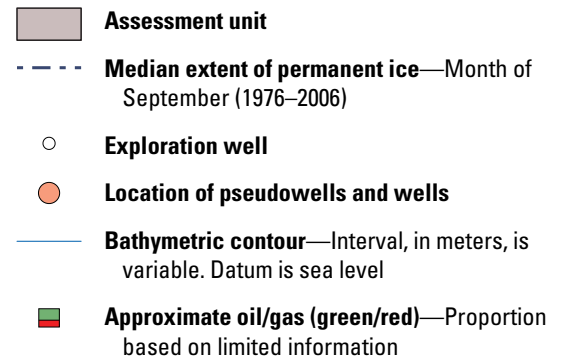

Accumulation of known size (scale below) showing oil/gas (green/red)—Proportion based on production and reserves data, in millions of barrels of oil equivalent, $M M B O E$ September (1976-2006)

16,384-32,768 MMBOE 512-1,024 MMBOE

8,192-16,384 MMBOE 256-512 MMBOE $4,096-8,192$ MMBOE 128-256 MMBOE 2,048-4,096 MMBOE - $64-28 \mathrm{MMBOE}$

1,024-2,048 MMBOE - $<64$ MMBOE

Figure 9. Map of the Alaska Passive Margin Assessment Unit showing exploration wells and known petroleum accumulations in adjacent areas (there are no wells in this $A U$ ), line of cross sections shown in figures $2 A$ and $2 B$, and locations of pseudowells and wells for which petroleum systems plots are shown in figure 6 . 


\section{Timing and Preservation}

Oil generation may have begun in the Early Cretaceous and radiated outward to the east and north during the Tertiary as thick, progressively offlapping sequences were deposited. All potential traps are syndepositional, and so timing was excellent for early charging of relatively young reservoirs. The potential for preservation of reservoired hydrocarbons also is considered excellent, as suggested by hydrocarbon accumulations that have been discovered in similar sequences in adjacent AUs (Canning-Mackenzie Deformed Margin and Arctic Alaska Platform; Houseknecht and others, 2012a; Houseknecht and others, 2019 [this volume]). Thus, a timing and preservation probability of 1.0 is assigned (appendix 2).

\section{Analogs Used for Assessment}

Assessment input was influenced by the geology, sizes, and numbers of discovered accumulations in adjacent AUs (Houseknecht and others, 2012a; Houseknecht and others, 2019 [this volume]) and by the assessment of undiscovered resources conducted by the MMS (Scherr and Johnson, 1998; Minerals Management Service, 2006), which was largely based on the mapping of favorable trap geometries from 2-D seismic data. Although seismic data are available within the Alaska Passive Margin AU, they are limited to the southernmost portion of the AU. Analogs were selected from the USGS World Analog Database (Charpentier and others, 2008) in two stages: (1) results returned from a search of rifted passive margin architecture were culled by eliminating salt structures, basement-related normal faulting, carbonate reservoirs, and other inappropriate geological parameters, and (2) a search of gravity-induced growth-fault trap systems. The resulting analog set was edited to remove geological characteristics deemed inappropriate for this AU. The final analog set consists of 20 AUs (table 3 ).

\section{Assessment Inputs}

\section{Number of Accumulations}

The analog set displays an approximately log-normal distribution of accumulation density with many values between 0 and 0.2 and several values up to about 0.5 accumulations of at least $50 \mathrm{MMBOE} / 1,000 \mathrm{~km}^{2}$, and with two outliers at 0.8 and 1.2. Accordingly, input values of 1 ( 0.06 density) at the minimum, 20 ( 0.29 density) at the median, and 50 ( 0.58 density) at the maximum were selected (appendix 2).

Table 3. Assessment units used to constrain input parameters for the Alaska Passive Margin and Canada Passive Margin Assessment Units. Analog data from Charpentier and others (2008).

[AU, assessment unit; TPS, total petroleum system]

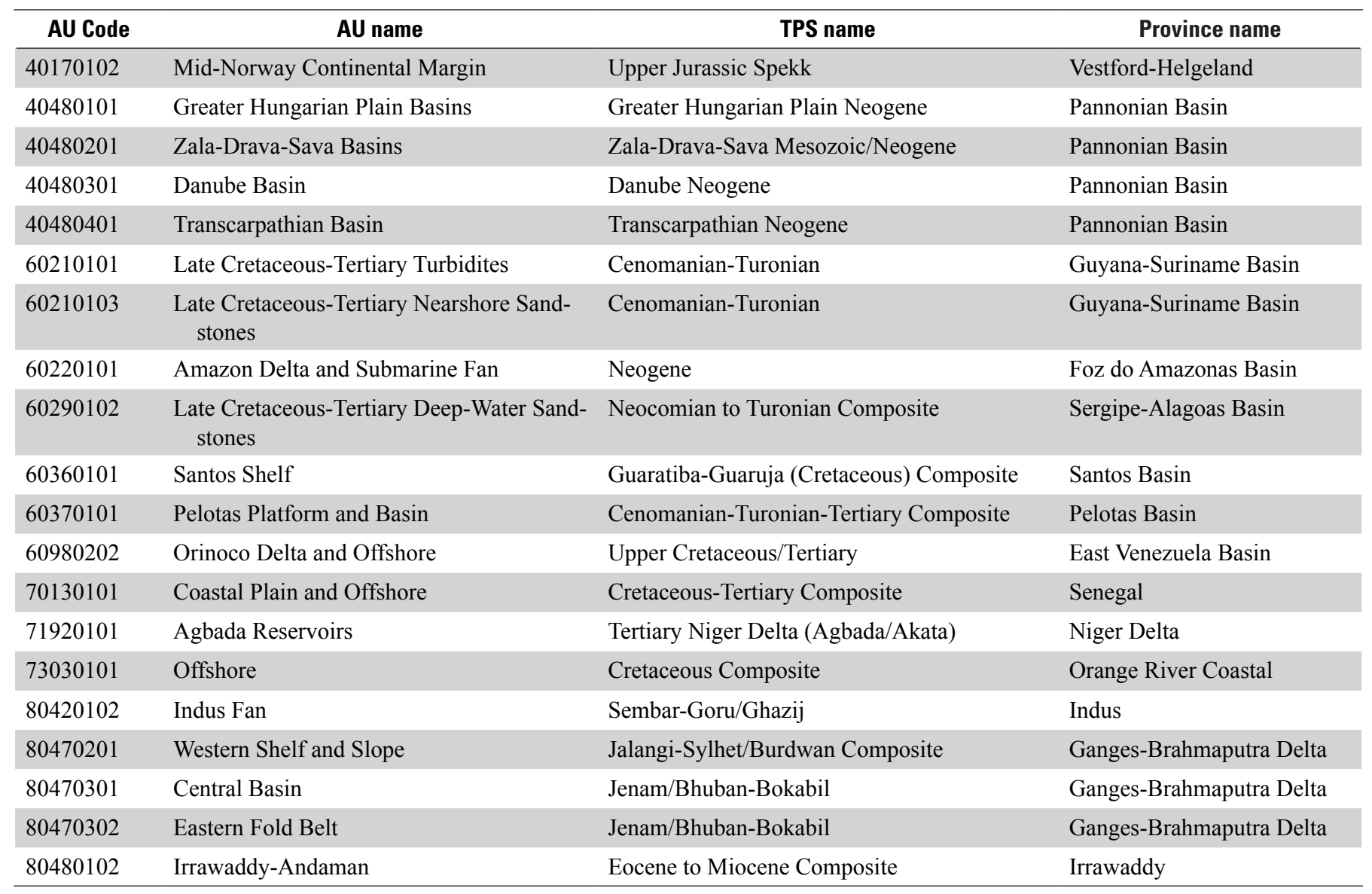




\section{Oil-to-Gas Mix}

The minimum, median, and maximum values of the oil-to-gas ratio were set at $0.4,0.7$, and 0.9 (appendix 2) on the basis of the expected similarity with the active petroleum system of the Canning-Mackenzie Deformed Margin AU. The higher value of 0.9 at the maximum reflects our interpretation that source rocks may be more oil-prone farther from the Mackenzie delta influx of terrigenous clastic sediment.

\section{Accumulation Size Distribution}

The median oil accumulation size was set at 100 MMBO (appendix 2) on the basis of the sizes of discovered accumulations in Tertiary sandstone reservoirs in adjacent AUs (Houseknecht and others, 2012a; Houseknecht and others, 2019 [this volume]); this value also closely matches the median and mean values of the median accumulation size in the analog set. The maximum oil accumulation size was set at 1 BBO (appendix 2) on the basis of the distribution of the largest known accumulations in the analog population, which is between 1 and 2 BBO. Median and maximum input values of $600 \mathrm{BCF}$ and $6 \mathrm{TCF}$ (appendix 2) were set for gas accumulation sizes by the same line of reasoning.

\section{Province Geologist's Estimated Maximum Accumulation Size}

Maximum accumulation sizes of 250-300 MMBO and 1-2 TCFG were selected on the basis of the size distribution of discovered accumulations in Tertiary reservoirs in adjacent AUs (Houseknecht and others, 2012a; Houseknecht and others, 2019 [this volume]), the largest accumulation sizes assessed by MMS (Sherwood and others, 1998; Minerals Management Service, 2006) using a large seismic database to constrain trap sizes, and analysis of seismic data available to the USGS. These maximum sizes, which did not enter directly into the volumetric calculations, were used to judge the reasonableness of the results of statistical analysis.

\section{Ancillary Properties and Co-Product Ratios}

Data from discovered pools in Tertiary sandstone reservoirs in adjacent AUs (Houseknecht and others, 2012a; Houseknecht and others, 2019 [this volume]) and expected geochemistry of potential source rocks were used to establish input values for these parameters.

\section{Results}

Probabilistic estimates of volumes of undiscovered, technically recoverable hydrocarbons for the Alaska Passive
Margin AU are summarized in table 2. These results include mean estimates of nearly $1 \mathrm{BBO}, 3 \mathrm{TCF}$ associated gas, and nearly 3 TCF nonassociated gas.

\section{Canada Basin Assessment Unit}

The Canada Basin AU contains no exploration wells and only sparse seismic data. This level of exploration places the Canada Basin into uncertainty category 4 on the scale used by the USGS for the Circum-Arctic Resource Appraisal (Charpentier and Gautier, 2011).

\section{Assessment Unit Description}

The southern and eastern boundaries of the Canada Basin AU are defined by the basinward limits of the Alaska Passive Margin, Canning-Mackenzie Deformed Margin, and Canada Passive Margin AUs. These boundaries are defined by a variety of geological, geophysical, and bathymetrical observations described in the descriptions of those adjacent AUs. The west boundary of the AU is the base of the Northwind escarpment along the east margin of the Chukchi Borderland, and the north boundary is defined by onlap thinning (to less than $2 \mathrm{~km}$ ) of Canada Basin strata onto the south margin of the Alpha-Mendeleev large igneous province (fig. 10). The Canada Basin AU encompasses an area of $673,000 \mathrm{~km}^{2}$.

This AU is characterized by a poorly known basement that may include highly attenuated continental and transitional crust, as well as oceanic crust inferred to be no younger than Barremian (Grantz and others, 1990b, 2009, 2011a, b), all overlain by a succession of Cretaceous and Cenozoic strata that mostly represents sediments dispersed from the Mackenzie delta and from other continental margins around the west (Chukchi Borderland), south (Arctic Alaska), and east (Arctic Canada) margins of the AU. The thickness of this sedimentary succession ranges from about $2 \mathrm{~km}$ in the northwest to more than $12 \mathrm{~km}$ in the southeast, adjacent to the Mackenzie delta (May and Grantz, 1990; Jackson and Oakey, 1990). The thickness of this sedimentary succession directly controls the bathymetry of the Canada Basin, with the thinnest succession underlying the deepest-water part of the basin and the thickest succession underlying the distal ramp of the Mackenzie delta (fig. 10).

No active petroleum systems are known in the Canada Basin AU; however, regional considerations suggest that shale representing organic-rich condensed sections likely are present in the Cretaceous and Paleogene parts of the succession. Modeling suggests that burial of these inferred source rocks beneath Cretaceous through Cenozoic strata has been sufficient to generate hydrocarbons in some - but not allparts of the AU (figs. 6, 7; Houseknecht and others, 2012b). 


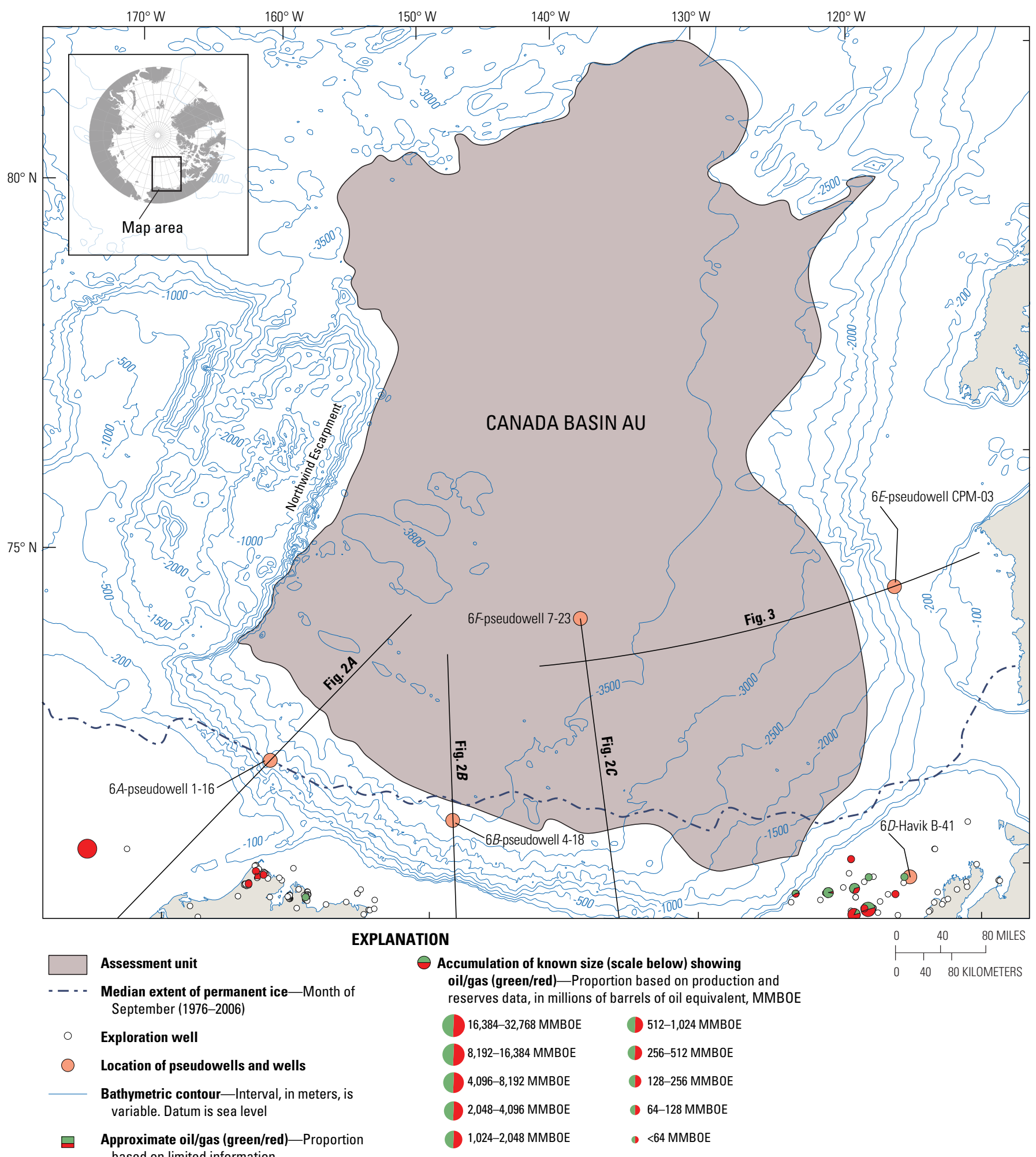

Figure 10. Map of the Canada Basin Assessment Unit showing exploration wells and known petroleum accumulations in adjacent areas (there are no wells in this $\mathrm{AU}$ ), lines of cross section shown in figures 2 and 3 , and locations of pseudowells and wells for which petroleum systems plots are shown in figure 6 . 


\section{Geologic Analysis of Assessment Unit Probability}

Available evidence suggests a generally unfavorable probability (less than 10 percent) for the presence of at least one accumulation of at least $50 \mathrm{MMBOE}$. Both charge and rocks are viewed as significant risk factors, as explained below.

\section{Charge}

There is no direct evidence of an active petroleum system in the Canada Basin AU. To the southeast, an active petroleum system is present in the Canning-Mackenzie Deformed Margin AU, with confirmed Tertiary oil in multiple discoveries larger than $50 \mathrm{MMBO}$ in the offshore Mackenzie delta region and in the Alaska Beaufort Sea immediately adjacent to the AU. Paleogene oil- and gas-prone mudstone and shale recovered by scientific drilling on Lomonosov Ridge suggest that source rocks may be present across the entire Amerasia Basin, an inference deemed probable based on tectonic and paleogeographic reconstructions. Upper Cretaceous shale, the distal equivalents of the Seabee Formation of Arctic Alaska, the Smoking Hills Formation of the Mackenzie delta region, and the lower part of the Kanguk Formation in the Canadian Arctic Islands, are likely present and may include oil-prone source rocks throughout the AU (Houseknecht and Bird, 2011). Regional tectonic and paleogeographic reconstructions suggest that it also is possible that Jurassic-Lower Cretaceous synrift and postrift source rocks may be present in the AU. Modeling (fig. $6 F$ ) suggests that oil generation likely began along the southern and eastern margins of the AU during the Miocene and migrated basinward to the present (Houseknecht and others, 2012b) and that hydrocarbon generation sufficient to generate at least one accumulation of the minimum size probably has occurred across 20 to 40 percent of the area of the AU. On the basis of this mostly circumstantial evidence, a charge probability of 0.5 is assigned to this AU.

\section{Rocks}

The potential exists in the Canada Basin for prospective strata ranging in age from Jurassic through Neogene. Jurassic to Lower Cretaceous strata may occur in rift basins around the western (Chukchi Borderland), southern (Arctic Alaska), and eastern (Arctic Canada) margins of the AU. If present, these strata are likely buried beneath 3 to $10 \mathrm{~km}$ of Upper Cretaceous through Cenozoic strata, and the probability that reservoir quality and trap geometry are preserved beneath this overburden is considered low. Lower Cretaceous through Cenozoic strata probably are mostly distal facies associated with sediment dispersal systems emanating from the Mackenzie delta and the Alaska and Canada Passive Margins. Although sand-prone turbidite facies may be present in these strata, it is likely they are fine grained, and the probability that their volume and reservoir quality are sufficient to trap at least $50 \mathrm{MMBOE}$ in an individual accumulation is considered low. The AU probably contains mostly stratigraphic trap geometries related to deepwater sediment-gravity-flow and turbidite depositional systems, and the presence of structural traps is unlikely. A rock probability of 0.1 is assigned on the basis of this generally unfavorable analysis.

\section{Timing and Preservation}

Hydrocarbon generation probably began in the south and east margins of the AU during the Miocene and migrated towards the central part of the $\mathrm{AU}$ to the present; hydrocarbon generation probably has not occurred in the western and northern parts of the AU (Houseknecht and others, 2012b). Because potential traps in the Canada Basin are mostly stratigraphic, the timing for entrapment and preservation of charge is favorable. Thus, a timing and preservation probability of 1.0 is assigned.

The probabilities discussed above yield an $\mathrm{AU}$ probability of only 0.05 ; therefore, no quantitative assessment of petroleum potential was conducted.

\section{Canada Passive Margin Assessment Unit}

The Canada Passive Margin AU contains no exploration wells, and no seismic data had been collected within it at the time of the 2008 assessment. This level of exploration places the Canada Passive Margin AU into uncertainty category 5 on the scale used by the USGS for the Circum-Arctic Resource Appraisal (Charpentier and Gautier, 2011).

\section{Assessment Unit Description}

The Canada Passive Margin is an elongate AU (fig. 11) whose major southeastern and northwestern boundaries are mapped on the basis of a horizontal gradient magnitude map of free air gravity anomalies (generated by R. Saltus of the USGS from data compiled by Forsberg, 2006; also see an updated gravity map in Gaina and others, 2011). This map was used to infer the inboard and outboard margins of a thick prism of sediment deposited following the rift opening of the Amerasia Basin. The AU is roughly equivalent to the "Canadian polar margin" of some publications (for example, Jackson, 1990). The inboard margin of the AU corresponds to the northern margin (hinge) of the Canada rift shoulder (Sverdrup rim). The outboard margin corresponds roughly with the base of the marine slope (approximately 3,000 $\mathrm{m}$ water depth) and with basinward thinning of the sediment prism as inferred by Jackson and Oakey (1990). The short southwestern boundary of the AU is defined by the approximate basinward limit of contractional folding in the Canning-Mackenzie Deformed Margin AU. The short northeastern boundary of the AU is 


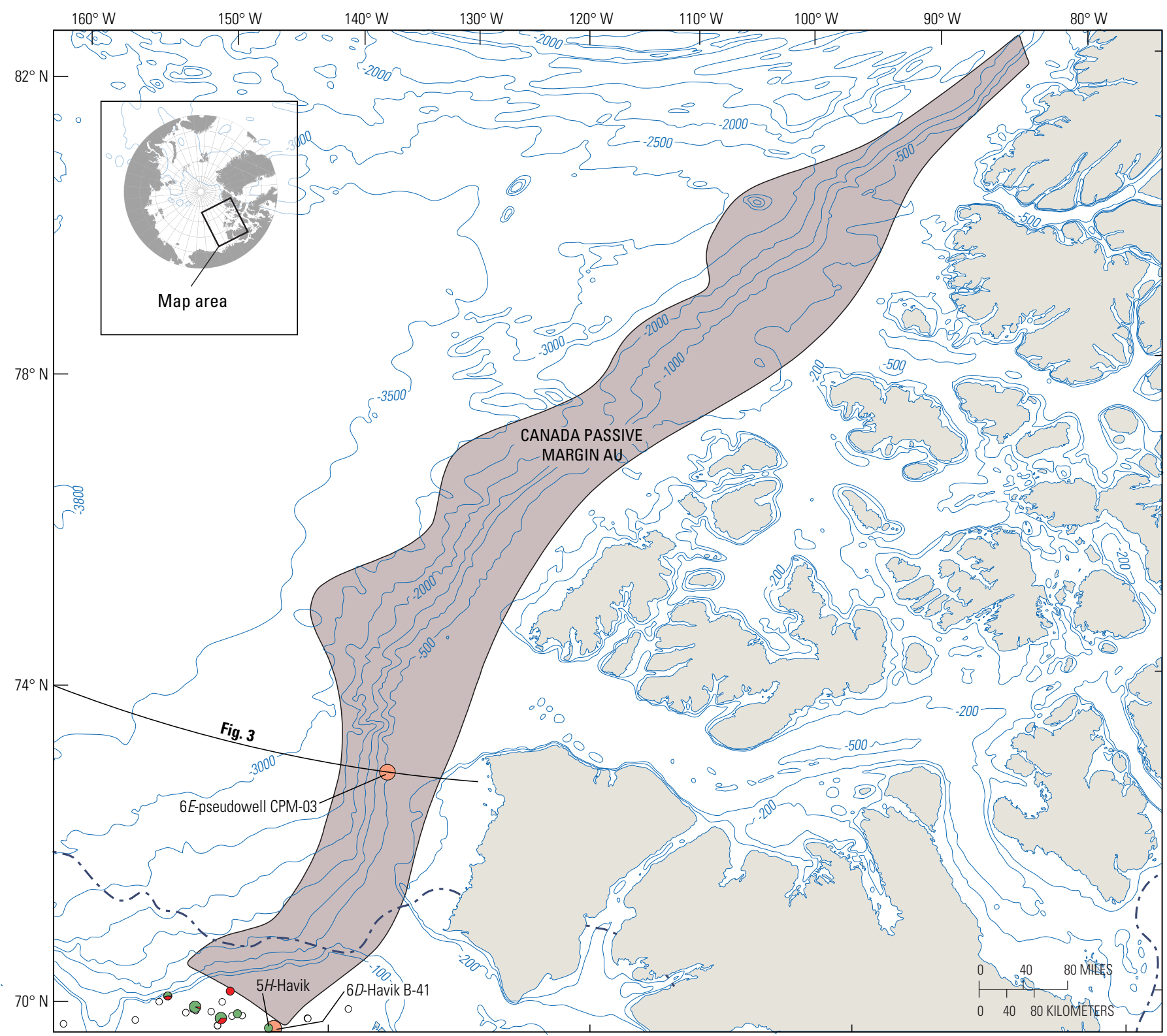

EXPLANATION

Assessment unit

- - - Median extent of permanent ice-Month of September (1976-2006)

Exploration well

Location of pseudowells and wells

Bathymetric contour-Interval, in meters, is variable. Datum is sea level

$\square \quad$ Approximate oil/gas (green/red)—Proportion based on limited information
Accumulation of known size (scale below) showing oil/gas (green/red)-Proportion based on production and reserves data, in millions of barrels of oil equivalent, MMBOE

16,384-32,768 MMBOE 512-1,024 MMBOE

8,192-16,384 MMBOE 256-512 MMBOE

4,096-8,192 MMBOE 128-256 MMBOE

2,048-4,096 MMBOE

- 64-128 MMBOE

1,024-2,048 MMBOE

- $<64 \mathrm{MMBOE}$

Figure 11. Map of the Canada Passive Margin Assessment Unit showing exploration wells and known petroleum accumulations in adjacent areas (there are no wells in this $\mathrm{AU}$ ), line of cross section shown in figure 3 , and locations of pseudowells and wells for which petroleum systems plots are shown in figure 6 . 
defined by abrupt thinning of the sediment prism onto volcanic rocks of the Alpha ridge. The Canada Passive Margin AU encompasses an area of 278,000 $\mathrm{km}^{2}$.

The Canada Passive Margin AU lies mostly on highly extended continental or transitional crust that was attenuated during Jurassic to Early Cretaceous rift opening of the Canada Basin; the top of basement is inferred to lie at great depth (generally more than $10 \mathrm{~km}$ ). The AU is characterized by a thick succession of mostly Cenozoic strata that is likely growth faulted and overpressured, an inference based on analog margins in Arctic Alaska and elsewhere around the world. Cretaceous (and perhaps Jurassic) strata likely are present but are buried beneath such a great thickness of Cenozoic strata that they are not likely to be oil or gas prospective, although they may be considered as potential source rocks. Although no reflection seismic data were available in this $\mathrm{AU}$ at the time of assessment, it was inferred to contain large-displacement growth faults and gravity folds on the basis of the Alaska Passive Margin analog. This inference was confirmed, at least in the southwestern part of the AU, by recently collected seismic data (Helwig and others, 2011).

\section{Geologic Analysis of Assessment Unit Probability}

Even though no exploration wells have been drilled in the Canada Passive Margin AU, available evidence suggests a generally favorable probability for the presence of at least one accumulation of at least $50 \mathrm{MMBOE}$ (appendix 3). Charge is viewed as the greatest risk factor, as explained below.

\section{Charge}

There is no direct evidence of an active petroleum system in the Canada Passive Margin AU. To the southwest, an active petroleum system is present in the CanningMackenzie Deformed Margin AU, with confirmed Tertiary oil in multiple discoveries larger than $50 \mathrm{MMBO}$ in the offshore Mackenzie delta. Paleogene oil- and gas-prone source rocks recovered by scientific drilling on Lomonosov Ridge suggest that source rocks may be present across the entire Amerasia Basin, an inference deemed probable based on tectonic and paleogeographic reconstructions (Houseknecht and Bird, 2011). Upper Cretaceous shale, the distal equivalents of the Smoking Hills Formation of the Mackenzie delta region and the lower part of the Kanguk Formation in the Canadian Arctic islands, is likely present and may include oil-prone source rocks throughout the AU. Regional tectonic and paleogeographic reconstructions suggest that Jurassic-Lower Cretaceous synrift and postrift source rocks also are likely present in the AU. Although these strata would certainly be overmature today, hydrocarbons generated as the source rocks were buried through the oil window may be preserved. Modeling (fig. $6 E$ ) suggests that oil generation likely began inboard during the Late Paleogene and progressively migrated basinward through the Neogene. On the basis of this mostly circumstantial evidence, yet regionally favorable prognosis, a charge probability of 0.6 is assigned to this AU (appendix 3 ).

\section{Rocks}

The potential exists in the Canada Passive Margin for prospective strata ranging in age from Middle Jurassic through Neogene. Middle Jurassic to Lower Cretaceous strata were likely derived from the uplifted Canada rift shoulder (Embry and Dixon, 1990; Haimila and others, 1990) and may include sands derived from older sedimentary successions as well as from basement uplifts. Middle to Upper Cretaceous strata are likely mostly fine grained and may include volcanics and (or) volcaniclastics related to Alpha ridge magmatism; this is especially true in the northeastern part of the AU, near the focus of volcanic activity (Embry and Osadetz, 1988). Paleogene strata likely include relatively coarse-grained sands derived from nearby uplifts associated with the Eurekan orogeny, especially in the northeastern half of the AU (Miall, 1984, 1986, 1991; Harrison and others, 1999), and may include finer grained lithic sands derived from the Brooks Range via the Mackenzie delta sediment dispersal system in the south-western part of the AU (Dixon, 1996). Neogene and younger strata also are likely to include relatively coarsegrained sands derived from the Canadian Arctic Islands region and perhaps from the broader Canadian shield farther south (Miall, 1984, 1986, 1991). It is expected that sandstonemudstone reservoir-seal couplets are present in abundance and that a variety of growth-fault, gravity-fold, and stratigraphic trap geometries are present. The range of trap types is likely similar to that of the Alaska Passive Margin, where the largest potential traps observed in seismic data are large-displacement (hundreds of meters) growth-fault systems; smaller potential traps may include lowstand, shelf-margin truncations and channelized facies in both deepwater and shallow-water facies. Relative to the Alaska Passive Margin, reservoir quality may be better in the Canada Passive Margin because the provenance of sands is more favorable for coarser grained and less lithic compositions. A rock probability of 0.9 is assigned on the basis of this generally favorable analysis (appendix 3 ).

\section{Timing and Preservation}

Oil generation probably began inboard during the Paleogene and migrated outward to the northwest through the Neogene as thick, progressively offlapping sequences were deposited (fig. 3). All potential traps are syndepositional, so timing was excellent for charging relatively young reservoirs. The potential for preservation of reservoired hydrocarbons also is considered excellent, as suggested by hydrocarbon accumulations that have been discovered in similar sequences in the adjacent Canning-Mackenzie Deformed Margin AU. Thus, a timing and preservation probability of 1.0 is assigned (appendix 3). 


\section{Analogs Used for Assessment}

Assessment input was influenced by the geology, sizes, and numbers of discovered accumulations in the adjacent Canning-Mackenzie Deformed Margin AU. Analogs were selected from the USGS World Analog Database (Charpentier and others, 2008) in two stages: (1) results of a search for rifted passive margin architecture was culled by eliminating salt structures, basement-related normal faulting, carbonate reservoirs, and other inappropriate geological parameters, and (2) a search of gravity-induced growth fault trap systems. The final analog set is the same as that used for the Alaska Passive Margin AU and consists of 20 AUs (table 3).

\section{Assessment Inputs}

\section{Number of Accumulations}

The analog set displays an approximate log-normal distribution of accumulation density with many values between 0 and 0.2 and several values up to about 0.5 accumulations of at least $50 \mathrm{MMBOE} / 1,000 \mathrm{~km}^{2}$, and with two outliers at 0.8 and 1.2. Accordingly, input values of 1 ( 0.00 density) at the minimum, 40 ( 0.14 density) at the median, and 150 (0.54 density) at the maximum were selected (appendix 3 ). This input reflects a large range of uncertainty appropriate for this frontier basin.

\section{Oil-to-Gas Mix}

The minimum, median, and maximum values of the oil-to-gas ratio were set at $0.4,0.7$, and 0.9 (appendix 3 ) on the basis of the expected similarity with the active petroleum system of the Canning-Mackenzie Deformed Margin AU. The higher value of 0.9 at the maximum reflects the interpretation that source rocks would likely be more oil-prone farther from the Mackenzie River delta influx of terrigenous clastic sediment.

\section{Accumulation Size Distribution}

The median oil accumulation size was set at 125 MMBO (appendix 3) on the basis of the sizes of discovered accumulations in Tertiary sandstone reservoirs in adjacent AUs and the expectation that reservoir quality will be somewhat better than in the Alaska Passive Margin AU; this value also closely matches the median and mean values of the median accumulation size in the analog set. The maximum oil accumulation size was set at $2 \mathrm{BBO}$ (appendix 3 ) on the basis of the largest accumulations discovered in analog areas (1 to $2 \mathrm{BBO}$ ). For maximum accumulation size, a value larger than used for the Alaska Passive Margin AU was specified, because of an indication that the Canada Passive Margin AU may contain a thicker sediment prism (possibly larger displacement growth-fault traps) and coarser grained sandstone (possibly larger reservoir volume). Median and maximum input values of $750 \mathrm{BCF}$ and $12 \mathrm{TCF}$ (appendix 3) were set for gas accumulation sizes by the same line of reasoning.

\section{Estimated Maximum Accumulation Size}

Maximum accumulation sizes of 300 to $400 \mathrm{MMBO}$ and 2 to 3 TCFG were selected on the basis of the size distribution of discovered accumulations in Tertiary reservoirs in adjacent AUs, the largest accumulation sizes assessed by the Minerals Management Service in the analog Alaska Passive Margin using a large seismic database to constrain trap sizes, and the inferences that traps may be larger and reservoir quality may be better in this AU. These maximum sizes, which did not enter directly into the volumetric calculations, were used to judge the reasonableness of the results of statistical analysis.

\section{Ancillary Properties and Co-Product Ratios}

Data from discovered pools in Tertiary sandstone reservoirs in adjacent AUs (Houseknecht and others, 2012a; Houseknecht and others, 2019 [this volume]) and expected geochemistry of potential source rocks were used to establish input values for these parameters.

\section{Results}

Probabilistic estimates of volumes of undiscovered, technically recoverable hydrocarbons for the Canada Passive Margin AU are summarized in table 2. These results include mean estimates of more than $2 \mathrm{BBO}$, more than $7 \mathrm{TCF}$ associated gas, and nearly 8 TCF nonassociated gas.

\section{Summary and Conclusions}

The Amerasia Basin was divided into four assessment units (AUs) for appraisal of undiscovered petroleum resources in conventional accumulations. Three of the AUs - the Alaska Passive Margin, the Canning-Mackenzie Deformed Margin, and the Canada Passive Margin — comprise sediment prisms deposited basinward of rift shoulders after tectonic opening of the Canada Basin. All three of the rifted margin sediment prisms are characterized by thick (more than $10 \mathrm{~km}$ ), growthfaulted, sandstone and mudstone successions that locally include gravity fold-and-thrust systems. The Canning-Mackenzie Deformed Margin AU is further characterized by ongoing contractional deformation related to northward advancement of the Brooks Range tectonic front. The deepwater Canada Basin AU is characterized by a succession of Cretaceous and Cenozoic strata that mostly represents sediments dispersed from the Mackenzie River delta and from other continental margins around the west (Chukchi Borderland), south (Arctic Alaska), and east (Arctic Canada) margins of the basin. 
Except for the Canning-Mackenzie Deformed Margin AU, where an active petroleum charge has been documented by exploration and discoveries, the potential for oil-prone source rocks across the region is inferred from indirect evidence. Stratigraphic and geochemical data in Alaska and Canada, inboard from the rift shoulders, and regional paleogeographic reconstructions suggest source-rock potential in Lower Cretaceous (Hauterivian-Albian), Upper Cretaceous (mainly Turonian), and lower Paleogene strata. Burial history modeling indicates favorable timing of oil generation (relative to trap formation) beneath the Canning-Mackenzie Deformed Margin, the Alaska and Canada Passive Margins, and a large part of the deep Canada Basin.

The Canning-Mackenzie Deformed Margin hosts numerous oil and gas discoveries in traps that include detachment anticlines and thrust-fault closures (both of tectonic and gravity origin), growth-fault blocks, stratigraphic pinch-outs, and perhaps closures formed by mud diapirs. Trap potential in the Alaska and Canada Passive Margin AUs primarily involves growth-fault blocks, stratigraphic pinch-outs, and perhaps gravity fold-and-thrust closures. Trap potential in the deep Canada Basin AU is limited to stratigraphic geometries in distal turbidite facies.

Assessment of undiscovered, technically recoverable petroleum resources in conventional accumulations of at least 50 MMBOE yields the following mean estimates: CanningMackenzie Deformed Margin AU, more than 6 BBO, nearly $20 \mathrm{TCF}$ of associated gas, and $16 \mathrm{TCF}$ of nonassociated gas; Canada Passive Margin AU, more than 2 BBO, more than 7 TCF of associated gas, and nearly 8 TCF of nonassociated gas; and Alaska Passive Margin AU, nearly 1 BBO, 3 TCF of associated gas, and nearly 3 TCF of nonassociated gas. No quantitative assessment was completed for the deep Canada Basin AU because the overall probability for the occurrence of at least one accumulation of at least $50 \mathrm{MMBOE}$ was estimated to be less than 10 percent.

\section{Acknowledgments}

This report was improved as the result of constructive reviews by Kirk Sherwood (Bureau of Ocean Energy Management), David Hite (Consulting Petroleum Geologist, Anchorage), and Jim Coleman.

\section{References Cited}

Balkwill, H.R., Cook, D.G., Detterman, R.L., Embry, A.F., Hakansson, E., Miall, A.D., Poulton, T.P. and Young, F.G., 1983, Arctic North America and northern Greenland, in Moullade, M., and Nairn, A.E.M., eds., The Phanerozoic geology of the world II; the Mesozoic, B: Elsevier, Amsterdam, p. 1-31.
Bergquist, C.L., Graham, P.P., Johnston, D.H., and Rawlinson, K.R., 2003, Canada's Mackenzie delta-Fresh look at an emerging basin: Oil and Gas Journal, v. 101, p. 42-46.

Bird, K.J., 1985, The framework geology of the North Slope of Alaska as related to oil-source rock correlations, in Magoon, L.B., and Claypool, G.E., eds., Alaska North Slope oil/rock correlation study: American Association of Petroleum Geologists, Studies in Geology 20, p.3-29.

Bird, K.J., 2001, Alaska-A twenty-first-century petroleum province, in Downey, M.W., Threet, J.C., and Morgan, W.A., eds., Petroleum provinces of the twenty-first century: American Association of Petroleum Geologists Memoir 74, p. $137-165$.

Bird, K.J., Burruss, R.C., and Pawlewicz, M.J., 1999, Thermal maturity, in U.S. Geological Survey, ANWR Assessment Team, The oil and gas resource potential of the Arctic National Wildlife Refuge 1002 area, Alaska: U.S. Geological Survey Open-File Report 98-34, 64 p., accessed March 21, 2012, at http://energy.cr.usgs.gov/OF98-34/VR.pdf.

Bird, K.J., Charpentier, R.R., Gautier, D.L., Houseknecht, D.W., Klett, T.R., Pitman, J.K., Moore, T.E., Schenk, C.J., Tennyson, M.E., and Wandrey, C.R., 2008, Circum-Arctic Resource Appraisal-Estimates of undiscovered oil and gas north of the Arctic Circle: U.S. Geological Survey Fact Sheet 2008-3049, 4 p., accessed November 30, 2011, at http://pubs.usgs.gov/fs/2008/3049/.

Bird, K.J., and Houseknecht, D.W., 2011, Geology and petroleum potential of Arctic Alaska, in Spencer, A.M., Embry, A.F., Gautier, D.L., Stoupakova, A.V., and Sørensen, K., eds., Arctic petroleum geology: Geological Society of London Memoir 35, p. 485-499.

Brinkhuis, H., Schouten, S., Collinson, M.E., Sluijs, A., Sinninghe Damste, J.S., Dickens, G.R., Huber, M., Cronin, T.M., Onodera, J., Takahashi, K., Bujak, J.P., Stein, R., van der Burgh, J., Eldrett, J.S., Harding, I.C., Lotter, A.F., Sangiorgi, F., van Konijnenburg-van Cittert, H., de Leeuw, J.W., Matthiessen, J., Backman, J., Moran, K., and the Expedition 302 Scientists, 2006, Episodic fresh surface waters in the Eocene Arctic Ocean: Nature, v. 441, p. 606-609.

Brooks, P.W., 1986a, Unusual biological marker geochemistry of oils and possible source rocks, offshore BeaufortMackenzie delta, Canada: Organic Geochemistry, v. 10, p. 401-406.

Brooks, P.W., 1986b, Biological marker geochemistry of crude oils and condensates from the Beaufort-Mackenzie basin: Bulletin of Canadian Petroleum Geology, v. 34, p. 490-505.

Burnham, A.K., and Sweeney, J.J., 1989, A chemical kinetic model of vitrinite maturation and reflectance: Geochimicaet Cosmochimica Acta, v. 53, p.2649-2657. 
Charpentier, R.R., 2017, Methodology for assessment of undiscovered oil and gas resources for the 2008 CircumArctic Resource Appraisal, chap. B of Moore, T.L., and Gautier, D.L., eds., The 2008 Circum-Arctic Resource Appraisal: U.S. Geological Survey Professional Paper 1824, 7 p., https://doi.org/10.3133/pp1824B.

Charpentier, R.R., and Gautier, D.L., 2011, U.S. Geological Survey Circum-Arctic Resource Appraisal (CARA) Introduction and summary of organization and methods, in Spencer, A.M., Embry, A.F., Gautier, D.L., Stoupakova, A.V., and Sørensen, K., eds., Arctic petroleum geology: Geological Society of London Memoir 35, p.145-150.

Charpentier, R.R., Klett, T.R., and Attanasi, E.D., 2008, Database for assessment unit-scale analogs (exclusive of the United States): U.S. Geological Survey Open-File Report 2007-1404, $61 \mathrm{p}$.

Chen, Z., Osadetz, K.G., Dixon, J., Morrell, G., and Dietrich, J.R., 2007, The future oil discovery potential of the Mackenzie/Beaufort province: American Association of Petroleum Geologists, Search and Discovery Article10133, 1 sheet, accessed November 30, 2011, at http://www. searchanddiscovery.net/documents/2007/07089chen02/.

Claypool, G.E., and Magoon, L.B., 1985, Comparison of oil-source rock correlation data for Alaskan North SlopeTechniques, results, and conclusions, in Magoon, L.B., and Claypool, G.E., eds., Alaska North Slope oil/ rock correlation study: American Association of Petroleum Geologists, Studies in Geology 20, p. 49-81.

Creaney, S., 1980, The organic petrology of the Upper Cretaceous Boundary Creek Formation, Beaufort-Mackenzie basin: Bulletin of Canadian Petroleum Geology, v. 28, p. $112-129$.

Dietrich, J.R., and Lane, L.S., 1992, Geology and structural evolution of the Demarcation subbasin and Herschel high, Beaufort-Mackenzie basin, Arctic Canada: Bulletin of Canadian Petroleum Geology, v. 40, p. 188-197.

Dixon, J., ed., 1996, Geologic atlas of the Beaufort-Mackenzie area: Geological Survey of Canada Miscellaneous Report $59,173 \mathrm{p}$.

Dixon, J., and Dietrich, J.R., 1990, Canadian Beaufort Sea and adjacent land areas, in Grantz, A., Johnson, L., and Sweeney, J.F., eds., The Arctic Ocean region: Boulder, Colo., Geological Society of America, The Geology of North America, v. L, p. 239-256.

Dixon, J., Dietrich, J.R., and McNeil, D.H., 1992, Upper Cretaceous to Pleistocene sequence stratigraphy of the Beaufort-Mackenzie and Banks Island areas, northwest Canada: Geological Survey of Canada Bulletin 407, 90 p.
Dixon, J., Morrel, G.R., Dietrich, J.R., Taylor, G.C., Procter, R.M., Conn, R.F., Dallaire, S.M., and Christie, J.A., 1994, Petroleum resources of the Mackenzie delta and Beaufort sea: Geological Survey of Canada Bulletin 474, 52 p.

Dumoulin, J.A., 2001, Lithologies of the basement complex (Devonian and older) in the National Petroleum Reserve-Alaska, in Houseknecht, D.W., ed., NPRA Core Workshop-Petroleum Plays and Systems in the National Petroleum Reserve-Alaska: SEPM CoreWorkshop 21, p. 201-214.

Embry, A.F., 1990, Geological and geophysical evidence in support of the hypothesis of anticlockwise rotation of northern Alaska: Marine Geology, v. 93, p. 317-329.

Embry, A.F., 1991, Mesozoic history of the Arctic islands, in Trettin, H.P., ed., Geology of the Innuitian orogen and Arctic platform of Canada and Greenland: Boulder, Colo., Geological Society of America, The Geology of North America, v. E, p. 371-433.

Embry, A.F., 1993, Crockerland-The northwest source area for the Sverdrup basin, Canadian Arctic islands, in Vorren, T.O., Bergsager, E., Dahl-Stamnes, Ø.A., Holter, E., Johansen, B., Lie, E., and Lund, T.B., eds., Arctic geology and petroleum potential: Norwegian Petroleum Society, Special Publication 2, p. 205-216.

Embry, A.F., 2000, Counterclockwise rotation of the Arctic Alaska plate-Best available model or untenable hypothesis for the opening of the Amerasia basin: Polarforschung, v. 68 , p. 247-255.

Embry, A.F., and Dixon, J., 1990, The breakup unconformity of the Amerasia basin, Arctic Ocean-Evidence from Arctic Canada: Geological Society of America Bulletin, v. 102, p. 1526-1534.

Embry, A.F., and Osadetz, K.G., 1988, Stratigraphy and tectonic significance of Cretaceous volcanism in the Queen Elizabeth Islands, Canadian Arctic archipelago: Canadian Journal of Earth Sciences, v. 25, p. 1209-1219.

Enachescu, M.E., 1990, Structural setting and validation of direct hydrocarbon indicators for Amauligak oil field, Canadian Beaufort Sea: American Association of Petroleum Geologists Bulletin, v. 74, p. 41-59.

Forsberg, R., 2006, Arctic gravity project data Web site: National Geospatial-Intelligence Agency, accessed November 30, 2011, at http://earth-info.nga.mil/GandG/ wgs84/agp/readme.html.

Forsyth, D.A., Asudeh, I., White, D., Jackson, R., Stephenson, R.A., Embry, A.F., and Argyle, M., 1998, Sedimentary basins and basement highs beneath the polar shelf north of Axel Heiberg and Meighen Islands: Bulletin of Canadian Petroleum Geology, v. 46, p. 12-29. 
Forsyth, D.A., Broome, J., Embry, A.F., and Halpenny, J.F., 1990, Features of the Canadian polar margin: Marine Geology, v. 93, p. 147-177.

Gaina, C., Werner, S.C., Saltus, R., Maus, S. and the Camp-GM Group, 2011, Circum-Arctic mapping projectNew magnetic and gravity anomaly maps of the Arctic, in Spencer, A.M., Embry, A.F., Gautier, D.L., Stoupakova, A.V., and Sørensen, K., eds., Arctic petroleum geology: Geological Society of London Memoir 35, p. 39-48.

Gautier, D.L., Bird, K.J., Charpentier, R.R., Grantz, A., Houseknecht, D.W., Klett, T.R., Moore, T.E., Pitman, J.K., Schenk, C.J., Schuenemeyer, J.H., Sørensen, K., Tennyson, M.E., Valin, Z.C., and Wandrey, C.J., 2009, Assessment of undiscovered oil and gas in the Arctic: Science, v. 324, p. 1175-1179.

Gautier, D.L., Bird, K.J., Charpentier, R.R., Grantz, A., Houseknecht, D.W., Klett, T.R., Moore, T.E., Pitman, J.K., Schenk, C.J., Schuenemeyer, J.H., Sørensen, K., Tennyson, M.E., Valin, Z.C., and Wandrey, C.J., 2011a, Oil and gas resource potential north of the Arctic Circle, in Spencer, A.M., Embry, A.F., Gautier, D.L., Stoupakova, A.V., and Sørensen, K., eds., Arctic petroleum geology: Geological Society of London Memoir 35, p. 151-161.

Gautier, D.L., Stemmerik, L., Christiansen, F.G., Sørensen, K., Bidstrup, T., Bojesen-Koefoed, J.A., Bird, K.J., Charpentier, R.R., Houseknecht, D.W., Klett, T.R., Schenk, C.J., and Tennyson, M.E., 2011b, Assessment of northeast Greenland-Prototype for development of Circum-Arctic Resource Appraisal methodology, in Spencer, A.M., Embry, A.F., Gautier, D.L., Stoupakova, A.V., and Sørensen, K., eds., Arctic petroleum geology: Geological Society of London Memoir 35, p. 663-672.

Grantz, A., Clark, D.L., Phillips, R.L., and Srivastava, S.P., 1998, Phanerozoic stratigraphy of Northwind Ridge, magnetic anomalies in the Canada basin, and the geometry and timing of rifting in the Amerasia basin, Arctic Ocean: Geological Society of America Bulletin, v. 110, p. 801-820.

Grantz, A., Dinter, D.A., and Culotta, R.C., 1987, Structure of the continental shelf north of the Arctic National Wildlife Refuge, in Bird, K.J., and Magoon, L.B., eds., Petroleum geology of the northern part of the Arctic National Wildlife Refuge, northeastern Alaska: U.S. Geological Survey Bulletin 1778, p. 271-276.

Grantz, A., Hart, P.E., and Childers, V.A., 2011a, Geologyand tectonic development of the Amerasia and Canada Basins, Arctic Ocean, in Spencer, A.M., Embry, A.F., Gautier, D.L., Stoupakova, A.V., and Sørensen, K., eds., Arctic petroleum geology: Geological Society of London Memoir 35, p. 771-799.
Grantz, A., and May, S.D., 1982, Rifting history and structural development of the continental margin north of Alaska, in Watkins, J.S., and Drake, C.L., eds., Studies in continental margin geology: American Association of Petroleum Geologists Memoir 34, p. 77-100.

Grantz, A., May, S.D., and Hart, P.E., 1990a, Geology of the Arctic continental margin of Alaska, in Grantz, A., Johnson, L., and Sweeney, J.F., eds., The Arctic Ocean region: Boulder, Colo., Geological Society of America, The Geology of North America, v. L, p. 257-288.

Grantz, A., May, S.D., Taylor, P.T., and Lawver, L.A., 1990b, Canada basin, in Grantz, A., Johnson, L., and Sweeney, J.F., eds., The Arctic Ocean region: Boulder, Colo., Geological Society of America, The Geology of North America, v. L, p. 379-402.

Grantz, A., Scott, R.A., Drachev, S.S., and Moore, T.E., 2009, Tectonostratigraphic accumulations of the Arctic Region $\left(65^{\circ}-90^{\circ} \mathrm{N}\right)$ that may be prospective for hydrocarbons: American Association of Petroleum Geologists GISUDRIL Open-File library, 4 sheets, scale 1:4,000,000 and explanatory pamphlet, $68 \mathrm{p}$.

Grantz, A., Scott, R.A., Drachev, S.S., Moore, T.E., and Valin, Z.C., 2011b, Sedimentary successions of the Arctic region $\left(58-64^{\circ}\right.$ to $\left.90^{\circ} \mathrm{N}\right)$ that may be prospective for hydrocarbons, in Spencer, A.M., Embry, A.F., Gautier, D.L., Stoupakova, A.V., and Sørensen, K., eds., Arctic petroleum geology: Geological Society of London Memoir 35, p. 17-37.

Haimila, N.E., Kirschner, C.E., Nassichuk, W.W., Ulmichek, G., and Procter, R.M., 1990, Sedimentary basins and petroleum resource potential of the Arctic Ocean region, in Grantz, A., Johnson, L., and Sweeney, J.F., eds., The Arctic Ocean region: Boulder, Colo., Geological Society of America, The Geology of North America, v. L, p. 503-538.

Harrison, J.C., Mayr, U., McNeil, D.H., Sweet, A.R., McIntyre, D.J., Eberle, J.J., Harington, C.R., Chalmers, J.A., Dam, G., and Nøhr-Hansen, H., 1999, Correlation of Cenozoic sequences of the Canadian Arctic region and Greenland-Implications for the tectonic history of northern North America: Bulletin of Canadian PetroleumGeology, v. 47, p. 223-254.

Hayba, D.O., Houseknecht, D.W., and Rowan, E., 1999, Stratigraphic, hydrogeologic, and thermal evolution of the Canning River region, North Slope, Alaska, in U.S. Geological Survey, ANWR Assessment Team, The oil and gas resource potential of the Arctic National Wildlife Refuge 1002 area, Alaska: U.S. Geological Survey OpenFile Report 98-34, 45 p., accessed November 30, 2011, at http://energy.cr.usgs.gov/OF98-34/FF.pdf. [As of December 2019, available online at https://pubs.usgs.gov/of/1998/ofr98-0034/FF.pdf.] 
Helwig, J., Kumar, N., Emmet, P., and Dinkelman, M.G., 2011, Regional seismic interpretation of crustal framework, Canadian Arctic passive margin, Beaufort Sea, with comments on petroleum potential, in Spencer, A.M., Embry, A.F., Gautier, D.L., Stoupakova, A.V., and Sørensen, K., eds., Arctic Petroleum Geology: Geological Society of London Memoir 35, p. 527-543.

Houseknecht, D.W., 2007, Cenozoic sedimentation associated with Brookian orogenic-wedge and Beaufort passive-margin gravity-fold-belt, northeastern Alaska [abs.]: International Conference on Arctic Margins, Tromsø, September 3-7, Abstracts and Proceedings of the Geological Society of Norway, p. 70-71.

Houseknecht, D.W., and Bird, K.J., 2006, Oil and gas resources of the Arctic Alaska petroleum province: U.S. Geological Survey Professional Paper 1732-A, 11 p., accessed November 30, 2011, at http://pubs.usgs.gov/pp/ pp1732/pp1732a/index.html.

Houseknecht, D.W., and Bird, K.J., 2011, Geology and petroleum potential of the rifted margins of the Canada basin in Spencer, A.M., Embry, A.F., Gautier, D.L., Stoupakova, A.V., and Sørensen, K., eds., Arctic petroleum geology: Geological Society of London Memoir 35, p. 509-526.

Houseknecht, D.W., Bird, K.J., and Garrity, C.P., 2012a, Assessment of undiscovered petroleum resources of the Arctic Alaska Petroleum Province: U.S. Geological Survey Scientific Investigations Report 2012-5147, 26 p. [Superseded by Houseknecht and others, 2019 (this volume).].

Houseknecht, D.W., Bird, K.J., and Garrity, C.P., 2019, Geology and assessment of undiscovered oil and gas resources of the Arctic Alaska Province, 2008, chap. E of Moore, T.E., and Gautier, D.L., eds., The 2008 Circum-Arctic Resource Appraisal: U.S. Geological Survey Professional Paper 1824, 26 p., https://doi.org/10.3133/pp1824E.

Houseknecht, D.W., Bird, K.J., and Schenk, C.J., 2009, Seismic analysis of clinoform depositional sequences and shelf-margin trajectories in Cretaceous (Albian) strata, Alaska North Slope: Basin Research, v. 21, p. 644-654.

Houseknecht, D.W., Burns, W.M., and Bird, K.J., 2012b, Thermal maturation history of Arctic Alaska and southern Canada basin, in Harris, N.B., and Peters, K.E., eds., Thermal history analysis of sedimentary basins - Methods and case histories: Society for Sedimentary Geology Special Publication 103, p. 199-219.

Hubbard, R.J., Edrich, S.P., and Rattey, R.P., 1987, Geologic evolution and hydrocarbon habitat of the "Arctic Alaska microplate": Marine and Petroleum Geology, v. 4, p. 2-34. Jackson, H.R., 1990, Evolution and regional stratigraphy of the northeastern Canadian polar margin: Marine Geology, v. 93, p. 179-192.
Jackson, H.R., and Oakey, G.N., 1990, Sedimentary thickness map of the Arctic Ocean, in Grantz, A., Johnson, L., and Sweeney, J. F., eds., The Arctic Ocean region: Boulder, Colo., Geological Society of America, The Geology of North America, v. L, plate 5.

Johnston, D., 2007, Prospectivity and hydrocarbon potential of the Mackenzie delta-Beaufort Sea petroleum province-A northern Gulf of Mexico waiting for its time [abs.]: Canadian Society of Petroleum Geologists, Gussow Conference abstract and online video, accessed November 30, 2011, at http://www.cspg.org/conventions/ abstracts/2007abstracts_gussow.htm.

Klett, T.R., and Pitman, J.K., 2011, Geology and petroleum potential of the East Barents Sea basins and Admiralty arch, in Spencer, A.M., Embry, A.F., Gautier, D.L., Stoupakova, A.V., and Sørensen, K., eds., Arctic petroleum geology: Geological Society of London Memoir 35, p. 295-310.

Klett, T.R., Wandrey, C.J., and Pitman, J.K., 2011, Geology and petroleum potential of the north and east margins of the Siberian craton, in Spencer, A.M., Embry, A.F., Gautier, D.L., Stoupakova, A.V., and Sørensen, K., eds., Arctic petroleum geology: Geological Society of London Memoir 35 , p. $413-431$.

Lane, L.S., 1997, Canada basin, Arctic Ocean-Evidence against a rotational origin: Tectonics, v. 16, p. 363-387.

Lane, L.S., 1998, Latest Cretaceous-Tertiary tectonic evolution of northern Yukon and adjacent Arctic Alaska: American Association of Petroleum Geologists Bulletin, v. 82, p. 1353-1371.

Lane, L.S., and Dietrich, J.R., 1995, Tertiary structural evolution of the Beaufort Sea-Mackenzie delta region, Arctic Canada: Bulletin of Canadian Petroleum Geology, v. 43, p. 293-314.

Lawver, L.A., Gahagan, L.M., and Norton, I., 2011, Palaeogeographic and tectonic evolution of the Arctic region during the Palaeozoic, in Spencer, A.M., Embry, A.F.,Gautier, D.L., Stoupakova, A.V., and Sørensen, K., eds., Arctic petroleum geology: Geological Society of London Memoir 35, p. 61-77.

Lawver, L.A., Grantz, A., and Gahagan, L.M., 2002, Plate kinematic evolution of the present Arctic region since the Ordovician, in Miller, E.L., Grantz, A., and Klemperer, S.L., eds., Tectonic evolution of the Bering shelf-Chukchi SeaArctic margin and adjacent landmasses: Geological Society of America Special Paper 360, p. 333-358.

Lawver, L.A., and Scotese, C.R., 1990, A review of tectonic models for the evolution of the Canada basin, in Grantz, A., Johnson, L., and Sweeney, J.F., eds., The Arctic Ocean region: Boulder, Colo., Geological Society of America, The Geology of North America, v. L, p.593-618. 
Leith, T.L., Weiss, H.M., Mørk, A., Århus, N., Elvebakk, G., Embry, A.F., Brooks, P.W., Stewart, K.R., Pchelina, T.M., Bro, E.G., Verba, M.L., Danyushevskaya, A., and Borisov, A.V., 1993, Mesozoic hydrocarbon source-rocks of the Arctic region, in Vorren, T.O., Bergsager, E., Dahl-Stamnes, Ø.A., Holter, E., Johansen, B., Lie, E., and Lund, T.B., eds., Arctic geology and petroleum potential: Norwegian Petroleum Society, Special Publication 2, p. 1-25.

Lerand, M., 1973, Beaufort Sea, in McCrossan, R.G., ed., The future petroleum provinces of Canada - Their geology and potential: Canadian Society of Petroleum Geology Memoir 1, p. 315-386.

Lillis, P.G., Lewan, M.D., Warden, A., Monk, S.M., and King, J.D., 1999, Identification and characterization of oil types and their source rocks, in U.S. Geological Survey, ANWR Assessment Team, The oil and gas resource potential of the Arctic National Wildlife Refuge 1002 area, Alaska: U.S. Geological Survey Open-File Report 98-34, 101 p., accessed November 30, 2011, at http://energy.cr.usgs.gov/ OF98-34/OA.pdf.

Magoon, L.B., 1994, The geology of known oil and gas resources by petroleum system - Onshore Alaska, in Plafker, G., and Berg, H.C., eds., The geology of Alaska: Geological Society of America, The Geology of North America, v. G-1, p. 905-936.

Magoon, L.B., Bird, K.J., Burruss, R.C., Hayba, D., Houseknecht, D.W., Keller, M.A., Lillis, P.G., and Rowan, E.L., 1999, Evaluation of hydrocarbon charge and timing using the petroleum system, in U.S. Geological Survey, ANWRAssessment Team, The oil and gas resource potential of the Arctic National Wildlife Refuge 1002 area, Alaska: U.S. Geological Survey Open-File Report 98-34, 66 p., accessed November 30, 2011, at http://energy.cr.usgs.gov/ OF98-34/PS.pdf.

Magoon, L.B., and Claypool, G.E., eds., 1985, Alaska North Slope oil/source rock correlation study: American Association of Petroleum Geologists, Studies in Geology 20, 685 p.

Magoon, L.B., Lillis, P.G., Bird, K.J., Lampe, C., and Peters, K.E., 2003, Alaskan North Slope petroleum systems: U.S. Geological Survey Open-File Report 03-324, 3 sheets, accessed November 30, 2011, at http://geopubs.wr.usgs.gov/ open-file/of03-324/.

Magoon, L.B., Woodward, P.V., Banet, A.C., Jr., Griscom, S.B., and Daws, T.A., 1987, Thermal maturity, richness, and type of organic matter of source-rock units, in Bird, K.J., and Magoon, L.B., eds., Petroleum geology of the northern part of the Arctic National Wildlife Refuge, northeastern Alaska: U.S. Geological Survey Bulletin 1778, p. 127-179.

Masterson, W.D., IV, 2001, Petroleum filling history of central Alaskan North Slope fields: University of Texas at Dallas, unpublished Ph.D. dissertation, $222 \mathrm{p}$.
Masterson, W.D., and Eggert, J.T., 1992, Kuparuk River field, North Slope, Alaska, in Beaumont, E.A., and Foster, N.H., eds., Stratigraphic traps III: American Association of Petroleum Geologists Treatise of Petroleum Geology, Atlas of Oil and Gas Fields, p. 257-284.

Masterson,W.D., and Paris, C.E., 1987, Depositional history and reservoir description of the Kuparuk River Formation, North Slope, Alaska, in Tailleur, I., and Weimer, P., eds., Alaskan North Slope geology: Pacific Section SEPM and Alaska Geological Society, p. 95-107.

May, S.D., and Grantz, A., 1990, Sediment thickness in the southern Canada basin: Marine Geology, v. 93, p. 331-347.

McMillen, K.J., and O'Sullivan, P., 1992, Tectonic and eustatic controls on Paleogene sequence stratigraphy, Beaufort Sea, Alaska and Canada, in Watkins, J.S., Zhiqiang, F., and McMillen, K.J. eds., Geology and geophysics of continental margins: American Association of Petroleum Geologists Memoir 53, p. 285-301.

McWhae, J.R., 1986, Tectonic history of the north Pacific, Canadian Arctic and Spitsbergen regions since Early Cretaceous time: American Association of Petroleum Geologists Bulletin, v. 70, p. 430-450.

Meneley, R.A., 1986, Oil and gas fields in the east coast and Arctic basins of Canada, in Halbouty, M.T., ed., Future petroleum provinces of the world: American Association of Petroleum Geologists Memoir 40, p. 143-176.

Miall, A.D., 1984, Sedimentation and tectonics of a diffuse plate boundary-The Canadian Arctic islands from $80 \mathrm{Ma}$ B.P. to the present: Tectonophysics, v. 107, p. 261-277.

Miall, A.D., 1986, The Eureka Sound Group (Upper Cretaceous-Oligocene), Canadian Arctic islands: Bulletin of Canadian Petroleum Geology, v. 34, p. 240-270.

Miall, A.D., 1991, Late Cretaceous and Tertiary basin development and sedimentation, Arctic islands, in Trettin, H.P., ed., Geology of the Innuitian orogen and Arctic platform of Canada and Greenland: Boulder, Colo., Geological Society of America, The Geology of North America, v. E, p. 437-458.

Minerals Management Service, 2006, Undiscovered oil and gas resources, Alaska Federal offshore as of 2006: Accessed November 30, 2011, at http://www.mms.gov/alaska/re/ reports/2006Asmt/index.HTM.

Molenaar, C.M., 1983, Depositional relations of Cretaceous and Lower Tertiary rocks, northeastern Alaska: American Association of Petroleum Geologists Bulletin, v. 67, p. 1066-1080. 
Moore, T.E., Grantz, A., Pitman, J.K., and Brown, P.J., 2011, A first look at the petroleum geology of the Lomonosov Ridge microcontinent, Arctic Ocean, in Spencer, A.M., Embry, A.F., Gautier, D.L., Stoupakova, A.V., and Sørensen, K., eds., Arctic petroleum geology: Geological Society of London Memoir 35, p.751-769.

Moore, T.E., and Pitman, J.K., 2011, Geology and petroleum potential of the Eurasia Basin, in Spencer, A.M., Embry, A.F., Gautier, D.L., Stoupakova, A.V., and Sørensen, K., eds., Arctic petroleum geology: Geological Society ofLondon Memoir 35, p.731-750.

Moore, T.E., Wallace, W.K., Bird, K.J., Karl, S.M., Mull, C.G., and Dillon, J.T., 1994, Geology of northern Alaska, in Plafker, G., and Berg, H.C., eds., The geology of Alaska: Boulder, Colo., Geological Society of America, The Geology of North America, v. G-1, p.49-140.

Mull, C.G., Houseknecht, D.W., and Bird, K.J., 2003, Revised Cretaceous and Tertiary stratigraphic nomenclature in the east-central Colville basin, northern Alaska: U.S. Geological Survey Professional Paper 1673, 51 p., accessed November 30, 2011, at http://pubs.usgs.gov/pp/p1673/.

National Energy Board (Canada), 1998, Probabilistic estimate of hydrocarbon volumes in the Mackenzie delta and Beaufort Sea discoveries, 8 p., accessed November 30, 2011, at http://www.neb-one.gc.ca/clf-nsi/rthnb/nrthffshr/pblctnrprt/ hydrcrbnvlm-eng.pdf.

Osadetz, K.G., Dixon, J., Dietrich, J.R., Snowdon, L.R., Dallimore, S.R., and Majorowicz, J.A., 2005, A review of Mackenzie Delta-Beaufort Sea petroleum province conventional and non-conventional (gas hydrate) petroleum reserves and undiscovered resources - A contribution to the resource assessment of the proposed Mackenzie Delta-Beaufort Sea marine protected areas: Geological Survey of Canada, Open File 4828, 31 p. plus figures and appendixes.

Paul, L.E., Choromanski, D.R., Turner, R.F., and Flett, T.O., 1994, Geological, geochemical, and operational summary, Aurora well, OCS Y-0943-1, Beaufort Sea, Alaska: Minerals Management Service, OCS Report MMS 94-0001, 71 p., $1 \mathrm{pl}$.

Peters, K.E., Magoon, L.B., Bird, K.J., Valin, Z.C., and Keller, M.A., 2006, North Slope Alaska-Source-rock distribution, richness, thermal maturity and petroleum charge: American Association of Petroleum Geologists Bulletin, v. 90, no. 2, p. 261-292.

Peters, K.E., Ramos, L.S., Zumberge, J.E., Valin, Z.C., and Bird, K.J., 2008, De-convoluting mixed crude oil in Prudhoe Bayfield, North Slope, Alaska: Organic Geochemistry, v. 39, p.623-645.

Schenk, C.J., 2011a, Geology and petroleum potential of the Timan-Pechora Basin province, Russia, in Spencer, A.M., Embry, A.F., Gautier, D.L., Stoupakova, A.V., and Sørensen, K., eds., Arctic petroleum geology: Geological Society of London Memoir 35, p. 283-294.
Schenk, C.J., 2011b, Geology and petroleum potential of the West Greenland-East Canada province, in Spencer, A.M., Embry, A.F., Gautier, D.L., Stoupakova, A.V., and Sørensen, K., eds., Arctic petroleum geology: Geological Society of London Memoir 35, p. 627-645.

Scherr, J., and Johnson, P., 1998, Beaufort shelf assessment province, in Sherwood, K.W., ed., Undiscovered oil and gas resources, Alaska Federal offshore: U.S. Minerals Management Service, OCS Monograph MMS 98-0054, p. 197-216.

Sherwood, K.W., Craig, J.D., Lothamer, R.T., Johnson, P.P., and Zerwick, S.A., 1998, Chukchi shelf assessment province, in Sherwood, K.W., ed., Undiscovered oil and gas resources, Alaska Federal offshore: Minerals Management Service, OCS Monograph MMS 98-0054, p. 115-196.

Sluijs, A., Schouten, S., Pagani, M., Woltering, M., Brinkhuis, H., Sinninghe Damste, J.S., Dickens, G.R., Huber, M., Reichart, G.-J., Stein, R., Matthiessen, J., Lourens, L.J., Pedentchouk, N., Backman, J., Moran, K., and the Expedition 302 Scientists, 2006, Subtropical Arctic Ocean temperatures during the Palaeocene/Eocene thermal maximum: Nature, v. 441, p. 610-613.

Snowdon, L.R., 1980, Petroleum source potential of the Boundary Creek Formation, Beaufort-Mackenzie basin: Bulletin of Canadian Petroleum Geology, v. 28, p. 46-58.

Snowdon, L.R., 1987, Organic properties and source rock potential of two early Tertiary shales, Beaufort-Mackenzie basin: Bulletin of Canadian Petroleum Geology, v. 35, p. 212-232.

Snowdon, L.R., Stasiuk, L.D., Robinson, R., Dixon, J., Dietrich, J., and McNeil, D.H., 2004, Organic geochemistry and organic petrology of a potential source rock of early Eocene age in the Beaufort-Mackenzie basin: Organic Geochemistry, v. 35, p. 1039-1052.

Sørensen, K., Gautier, D., Pitman, J., Jackson, H.R., and DahlJensen, T., 2011, Geology and petroleum potential of the Lincoln Sea basin, offshore north Greenland, in Spencer, A.M., Embry, A.F., Gautier, D.L., Stoupakova, A.V., and Sørensen, K., eds., Arctic petroleum geology: Geological Society of London Memoir 35, p. 673-684.

Stasiuk, L.D., Issler, D.R., Tomica, M., and Potter, J., 2005, Re-evaluation of thermal maturation-Vitrinite reflectance profiles for Cretaceous and Tertiary strata, BeaufortMackenzie basin, Northwest Territories (Adlartok P-09, Amerk O-09, Edlok N-56, Ikhil K-35, Sarpik B-35, Hansen G-07, and Havik B-41): Geological Survey of Canada, Open File 4665, 14 p.

Stein, R., 2007, Upper Cretaceous/lower Tertiary black shales near the North Pole-Organic-carbon origin and sourcerock potential: Marine and Petroleum Geology, v. 24, p. $67-73$.

Stein, R., Boucsein, B., and Meyer, H., 2006, Anoxia and high primary production in the Paleogene central Arctic OceanFirst detailed records from Lomonosov Ridge: Geophysical Research Letters, v. 33,L18606. 
Threlkeld, C.N., Obuch, R.C., and Gunther, G.L., 2000, Organic geochemistry data of Alaska: U.S.Geological Survey Digital Data Series DDS-59, accessed November 30, 2011, at http://pubs.usgs.gov/dds/dds-059/.

Tissot, B.P., and Welte, D.H., 1984, Petroleum formation and occurrence (2d ed.): New York, Springer-Verlag, 699 p.
Wicks, J.L., Buckingham, M.L., and Dupree, J.H., 1991, Endicott field-U.S.A., North Slope basin, Alaska, in Foster, N.H., and Beaumont, E.A., eds., Structural traps V: Ameri can Association of Petroleum Geologists Treatise of Petroleum Geology, Atlas of Oil and Gas Fields, p. 1-25.
Moffet Field Publishing Service Center, California

Manuscript approved for publication December 2, 2019 Edited by Claire Landowski

Layout and design by Kimber Petersen 
